\title{
Review of Multifunctional Inverter Topologies and Control Schemes Used in Distributed Generation Systems
}

\author{
Ahmet Teke ${ }^{\dagger}$ and Mohammad Barghi Latran* \\ $\dot{\dagger}^{*}$ Department of Electrical and Electronics Eng., Cukurova University, Adana, Turkey
}

\begin{abstract}
Recent developments in power electronics technology have spurred interest in the use of renewable energy sources as distributed generation (DG) generators. The key component in DG generators is a grid-connected inverter that serves as an effective interface between the renewable energy source and the utility grid. The multifunctional inverter (MFI) is special type of grid-connected inverter that has elicited much attention in recent years. MFIs not only generate power for DGs but also provide increased functionality through improved power quality and voltage and reactive power support; thus, the capability of the auxiliary service for the utility grid is improved. This paper presents a comprehensive review of the various MFI system configurations for single-phase (two-wire) and three-phase (three- or four-wire) systems and control strategies for the compensation of different power quality problems. The advances in practical applications and recent research on MFIs are presented through a review of nearly 200 papers.
\end{abstract}

Keywords: Distributed generation system, Mitigation of power quality problems, Multifunctional inverter, Renewable energy

\section{INTRODUCTION}

In recent years, the installation of more distributed generators (DG) in power distribution networks has elicited increased attention. A number of reasons can explain this trend. Such reasons include environmental concerns, electricity business restructuring, and the rapid development of small-scale power generation technologies and other micro-grid related devices and systems. In practice, DG units can be constructed with various renewable energy sources (RES). However, the real power output from these energy resources is essentially unstable. Given the increasing number of RESs and DG installations, new control strategies must be developed for the proper operation and management of new power grids embedded with DG units to maintain or improve system quality and reliability. Power electronics and smart technologies play an important role in DG operations, in which the effective integration of RES into the power grid is the major objective [1]-[6].

A comprehensive review of AC and DC micro-grid systems with RES-based DG units, energy storage devices, and loads available in recent literature was presented in [2]. A

Manuscript received Oct. 29, 2013; accepted Dec. 30, 2013

Recommended for publication by Associate Editor Rae-Young Kim.

${ }^{\dagger}$ Corresponding Author: ahmetteke@cu.edu.tr

Tel: +90-322-3386868, Fax: +90-322-3386326, Cukurova University

*Dept. of Electrical and Electronics Eng., Cukurova University, Turkey fuel cell system-based power generation system was presented in [7]-[9]. Several typical PV-based DG systems were designed in [10] and [11], and a DG system based on a wind power generator was presented in [12]. Utility is of concern because of the high penetration level of intermittent RES in distribution systems. This situation may cause a hazard to the network in terms of power quality (PQ), voltage regulation, and stability. The electric PQ guidelines and standard limits can be found in [13]-[19]. The negative effects of poor PQ were well investigated in [13], [14], and [17]-[19].

The relation between DG and PQ is ambiguous. Many authors have stressed the positive effects of DG on PQ problems. In [20], the sources of PQ problems in DG systems were analyzed; this study has contributed significantly to this new research field. In [21], [22], the resonance phenomenon in a PV plant was discussed to define the unwanted trip off of grid-tied inverters, a phenomenon that shows the significance and necessity significance of PQ enhancement in DG systems. In the field of exhaustive PQ evaluation, [23] presented several useful suggestions to form a quantitative exhaustive indicator, including various PQ indicators. Exhaustive evaluation can provide a decision on the existing PQ, which may be used as a reference for DG systems to manage their PQ. Therefore, DG systems must comply with technical and regulatory requirements to maintain the efficient, reliable and 


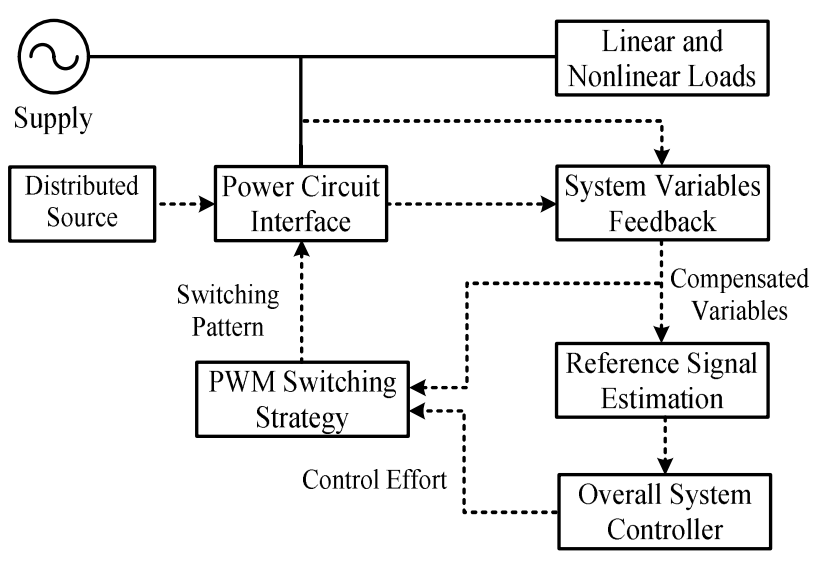

Fig. 1. Generalized block diagram of MFI.

safe operation of the overall grid. DG systems can be controlled efficiently to improve the system operation with enhanced PQ at the point of common coupling (PCC) with the advances in power electronics and digital control technologies [24]. Although the main purpose of DG systems is to provide active power, reactive power can be compensated and active power filter functionality can be achieved.

DG systems are tied to the utility grid either in series or in a shunt position. However, the target compensated quantities, such as harmonics, unbalance, and reactive power, are directly related to the currents. As such, the shunt type topology is widely utilized because it effectively injects compensating currents at PCC. In practical applications, the three-phase voltage source inverter (VSI) is widely used as the interface between RES-based DG generators and the utility grid. To develop a multifunctional DG inverter, the switching signals for VSI, which are by nature current signals, may include information on the active power supplied from RES and the reactive power required to compensate for the PQ disturbances at PCC [25], [26]. The general components of a common MFI system and their interconnections are shown in Fig. 1.

Measuring instruments, such as advanced metering infrastructures and demand energy management and protection systems, can also be integrated into MFIs. To achieve all these enhancements, current research is focused on determining details of utility grid applications, such as power supply for critical loads in commercial buildings, electronic factories, and hospitals. Results show a significant reduction in PQ problems, losses, and downtime and protection malfunctions [2], [27]-[29].

The present study also developed an abbreviated list of different MFI categories. A total of 10 abbreviations were identified: MFI-ML, MFI-VM, MFI-CM, MFI-ZM, MFI-DC, MFI-FC, MFI-CH, MFI-HM, MFI-MM, and MFI-DM. The most substantial control methods and approaches utilized to control MFIs are likewise presented in this paper.

\section{ClassifiCATION OF MFIS IN DG SYSTEMS}

MFIs can be classified into two major categories: power circuit structure of the MFI and compensated variable in PCC.

\section{A. Power Circuit Structure}

MFIs can be classified based on the power circuit structure utilized to solve PQ problems in a studied system as shown in Fig. 2. The important parameters ascribed to these classifications are the following: (1) type of power source, (2) inverter topology, and (3) power circuit configuration of the MFI. Newly developed topologies and/or power circuit configurations for MFIs are also presented in this section [26].

1) Classification according to the type of power source: AC loads or devices in the power system can be generally divided into single-phase and three-phase depending on whether the system is supplied by a single-phase (2-wire) or three-phase (3-wire or 4-wire) source. Various MFI configurations are employed to mitigate PQ disturbances from the system. The voltage-related PQ disturbances that occur in both single-phase and three-phase systems have similar characteristics. Additionally, three-phase systems require voltage unbalance compensation to satisfy the enhanced PQ.

The major issue in a single-phase system is the compensation for the reactive power and harmonic currents. In the case of a three-phase three-wire (3P3W) system, one must consider the current unbalance expected from the reactive current and current harmonics. A neutral current compensation loop is required for a three-phase four-wire (3P4W) system.

The most popular MFI system configuration that compensates for PQ disturbances in a single-phase two-wire (1P2W) supply system consists of two H-bridge inverters (total of four semiconductor switches) as shown in Fig. 3(a) [30]-[49]. Fig. 3(b) shows a single-phase three-wire (1P3W) half-bridge VSI topology that generates stable sinusoidal voltages or achieves PQ compensation [50]. In [51], a new active filtering technique was proposed as the interface between single-phase VSI and the utility grid. The technique involves the use of a single inverter with four legs (1P4L) as shown in Fig. 3(c). Two legs are utilized to construct a full bridge characterized by low switching frequency. The two other legs comprise a filter full bridge characterized by low power and high switching frequency.

Nonlinear loads, such as variable speed drives fed from a 3P3W system, AC-AC converters, arc welding devices, and arc furnaces, cause several PQ problems. A 3P3W VSI-based MFI is shown in Fig. 4. It is the most preferred MFI system [52]-[127]. Fig. 5 shows the circuit topology of a three-phase, two-leg, three-wire inverter that generates active power in the 


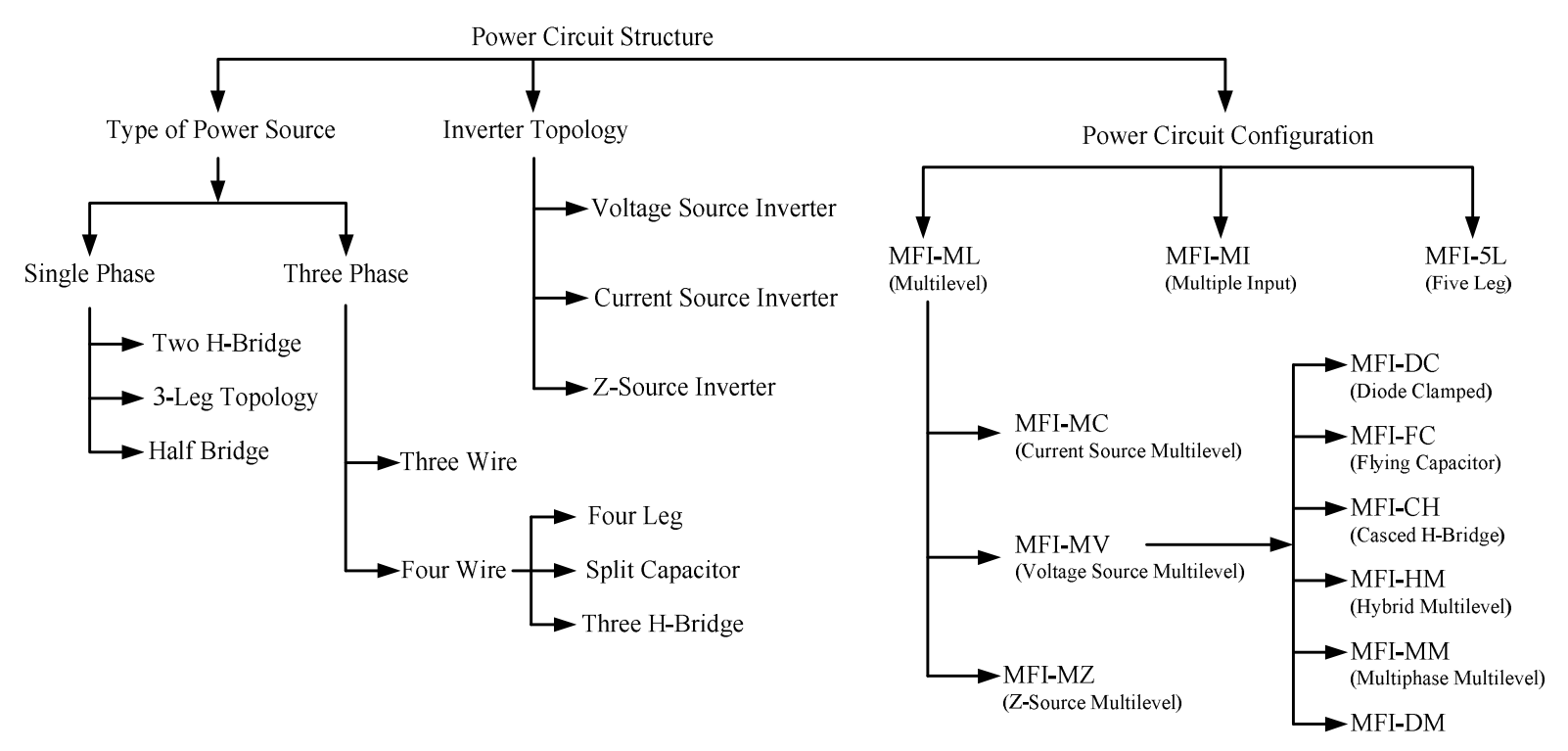

Fig. 2. Classification of MFI based on power circuit structure.

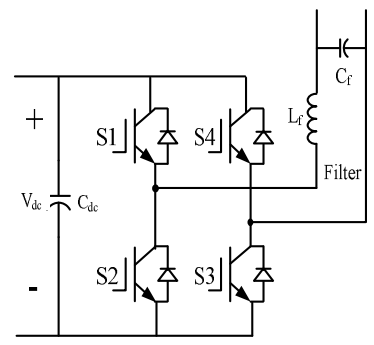

(a)

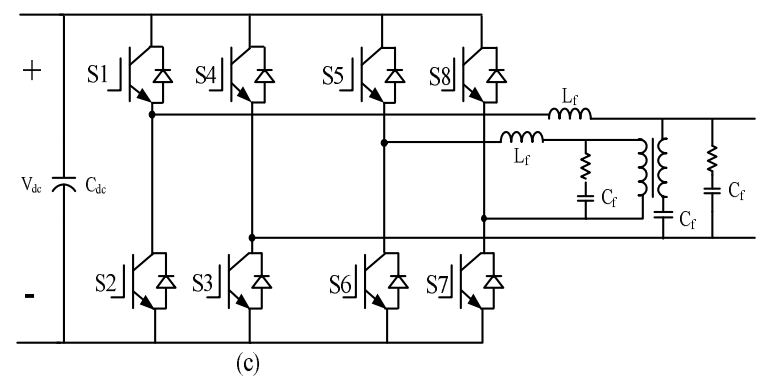

Fig. 3. (a) Configuration of $1 \mathrm{P} 2 \mathrm{~W}$ MFI H-bridge. (b) Configuration of 1P3W MFI. (c) Configuration of 1P4L MFI.

utility system to simultaneously achieve harmonic and reactive power compensation [128], [129]. Except for three-phase loads, some industrial facilities often consist of combined loads, such as a variety of single-phase and three-phase loads supplied by a 3P4W source.

A neutral conductor causes an excessive neutral current flow and thus demands additional compensation requirements in the presence of a fourth wire. To mitigate the neutral current in a $3 \mathrm{P} 4 \mathrm{~W}$ system, various shunt inverter configurations have been studied, namely, two-split capacitor (2C) [130], [131], four-leg capacitor (4L) [131]-[141], and three-H bridge (3HB).

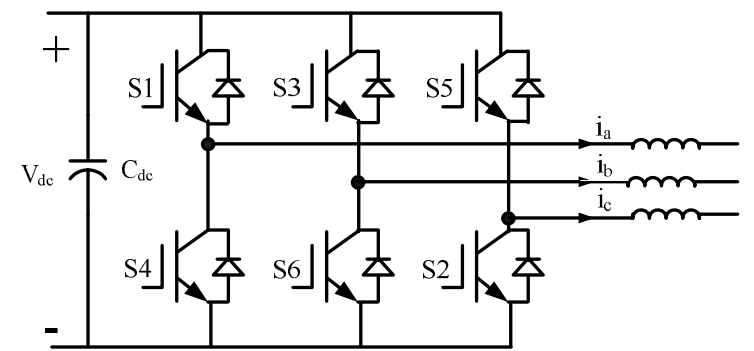

Fig. 4. Configuration of the 3P3W VSI-based MFI.

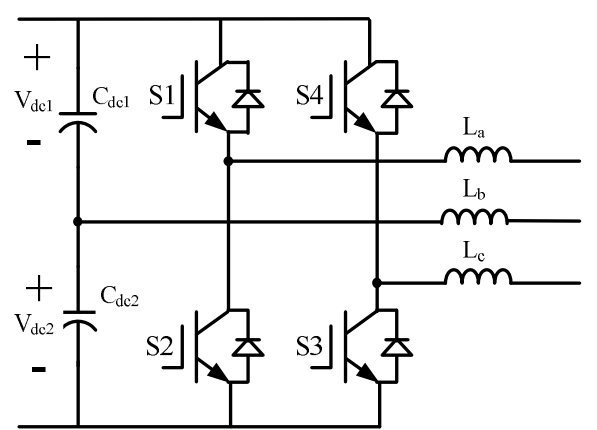

Fig. 5. Configuration of a 3P2L MFI.

Fig. 6 shows the 3P4W MFI configurations based on 2C, $4 \mathrm{~L}$, and $3 \mathrm{HB}$ topologies. The $2 \mathrm{C}$ topology consists of two split capacitors on the DC side. The midpoint of the capacitor is employed as a connection point for the fourth wire. In the $2 \mathrm{C}$ topology, equal voltages must be maintained in both capacitors to prevent the flow of circulating current as shown in Fig. 6(a). An additional control loop for DC bus capacitor voltage regulation is required for this type of topology.

An additional leg (two switching devices) is employed in the $4 \mathrm{~L}$ topology to compensate for the load neutral current as shown in Fig. 6(b). The 4L topology achieves superior 

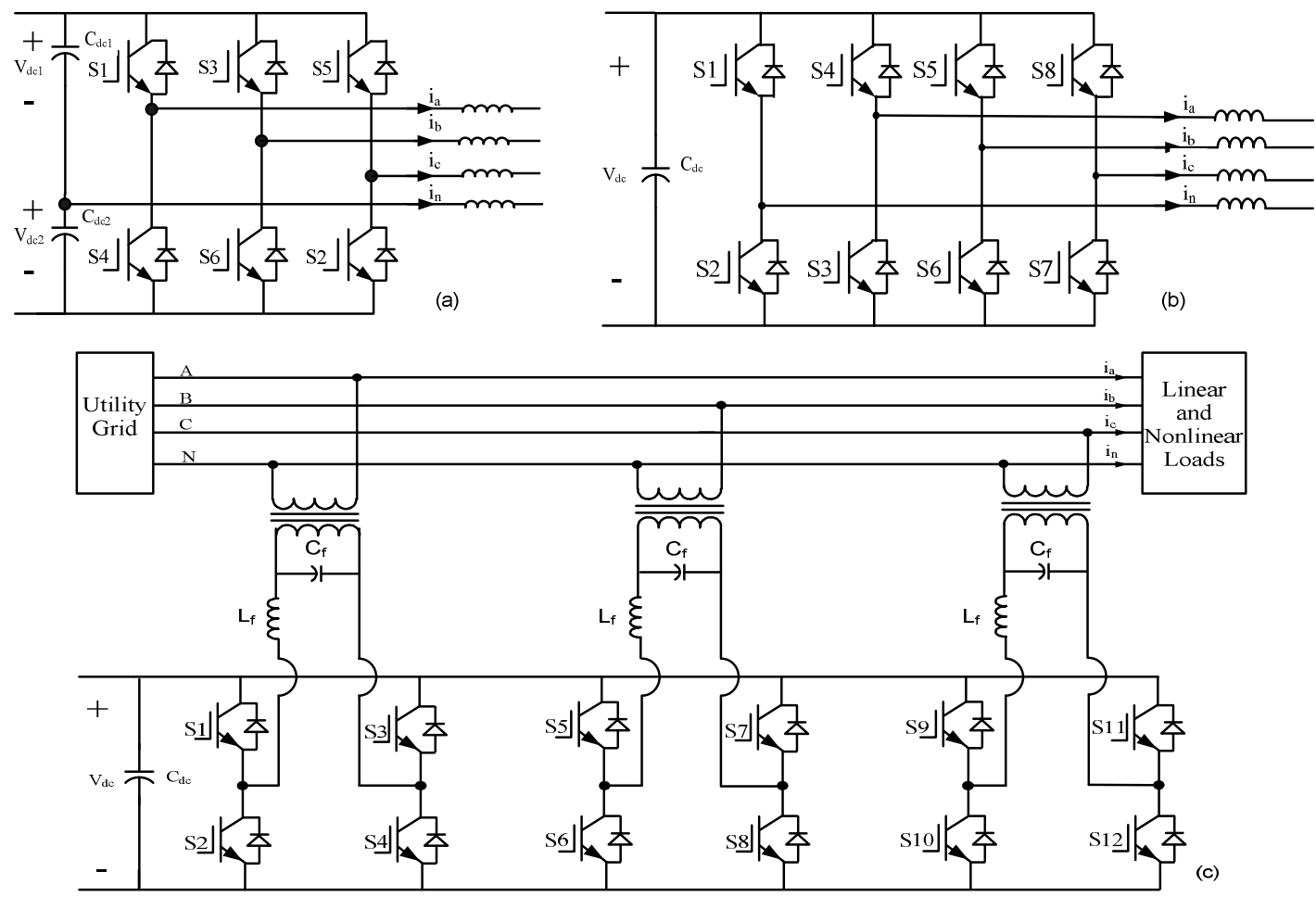

Fig. 6. Inverter topology of 3P4W MFI; (a) 2C shunt inverter topology; (b) 4L inverter topology; and (c) 3HB inverter topology.

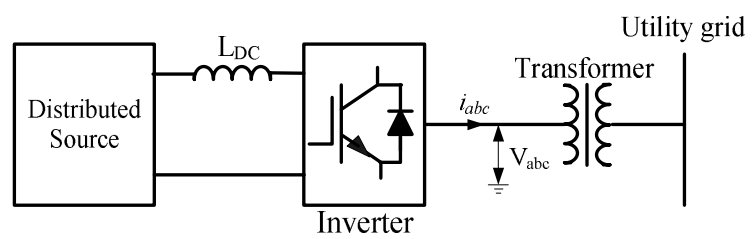

Fig. 7. Configuration of the CSI-based MFI.

control over neutral current through the use of a fourth leg. The 3HB topology involves the use of three units of single-phase H-bridge inverters connected to the common DC bus of the MFI. The MFI system configuration, in which the shunt inverter consists of three units of H-bridges, is shown in Fig. 6(c).

2) Classification according to inverter topology: In an MFI, both the inverter and rectifier use the common DC bus. The inverter maintains the DC link value at its set reference value. An MFI can be formed with a pulse-width modulated (PWM) current source inverter (CSI) [93], [100]-[103], which employs a common inductor $\mathrm{L}_{\mathrm{DC}}$ to develop the DC bus. Fig. 7 shows the configuration of a CSI-based MFI system. The CSI-based MFI topology is rarely used because of its high cost and losses.

The second topology, the most popular and common inverter topology for MFI, is PWM VSI. This topology involves the use of a common capacitor $\mathrm{C}_{\mathrm{DC}}$. Fig. 8 shows the single-line configuration of a VSI-based MFI. Most studies

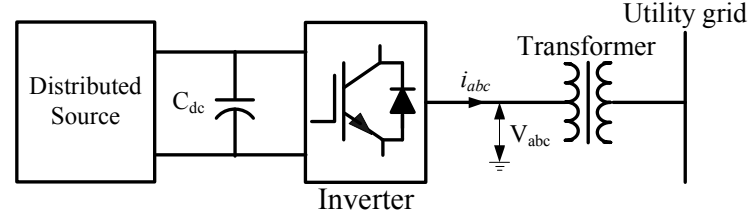

Fig. 8. Configuration of the VSI-based MFI.

on MFIs generally use the VSI-based topology. The VSI topology does not require blocking diodes; it is lighter in weight, cheaper, and allows for more flexible control than the CSI topology.

The third topology for MFI consists of a Z-source inverter (ZSI) that shares a common energy storage capacitor and an inductor. ZSI is different in structure from the conventional VSI or CSI because of the presence of X-shaped LC impedance shown in Fig. 9. ZSI allows for safe triggering through the inverter arms and the amplification of voltage across the Z-source capacitor through the inductors in the Z-source impedance network. With the rapid development in renewable energy technologies, ZSI topology provides DG operators greater flexibility in interfacing the generated energy to the utility grid [143]-[145]. In [146], a new topology called quasi-ZSI (qZSI) was proposed to generate power from a PV system with a battery. The battery is shunt, with one of the capacitors in quasi-Z-source (qZS) topology instead of a DC/DC converter. The system with battery support can improve the injected power in the utility grid when the PV power fluctuates as shown in Fig. 10. 


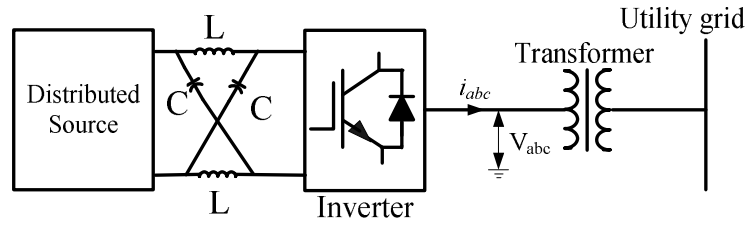

Fig. 9. Configuration of the ZSI-based MFI.

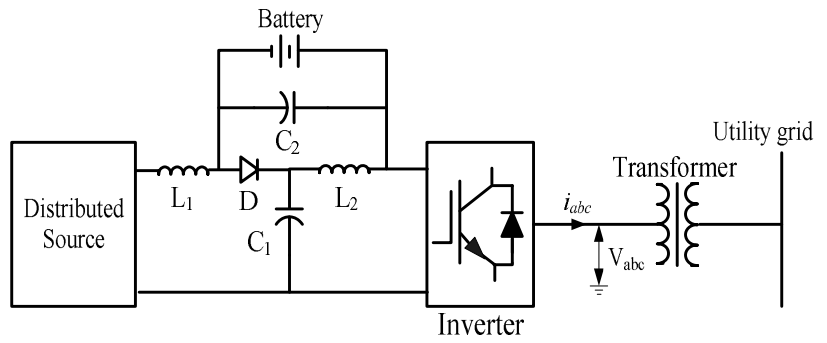

Fig. 10. Configuration of the qZSI-based MFI.

T-source inverter is a modified shape of ZSI, in which the number of passive components is reduced to further improve the ZSI's operation as studied in [108]. The configuration of the T-source inverter is shown in Fig. 11.

In [147], the three-phase five-leg topology (DC link is omitted; shown in Fig. 12) and its overall control are investigated. The performance of the systems is compared with that of the traditional six-leg topology. A five-leg converter is used to replace the traditional six-leg one while performing similar tasks. The structure and control of wind energy conversion systems (WECS) with an induction generator doubly fed by a five-leg converter are different from the traditional scheme with a six-leg converter. The number of output control signals can be reduced because the number of legs is reduced. Therefore, a modified PWM controller for a five-leg converter is preferred. The voltage reference generation units remain identical in both five- and six-leg cases. Thus, the generation of the desired two sets of three-phase voltages in the utility grid and rotor sides is possible with a suitable PWM control method.

Single-phase and three-phase VSIs coupled with isolating transformers are often preferred to ensure galvanic isolation and alter the output voltage value [129], [149]-[152]. In [153], a linear model in the stationary frame was developed for a VSI connected to the utility grid through $\Delta-\mathrm{Y}$ and $\mathrm{Y}-\mathrm{Y}$ transformers. The proposed model accounts for the phase shift caused by the $\Delta-Y$ transformer. This phase shift improves the system's dynamic and steady-state behavior in balanced and unbalanced conditions. According to the modal analysis performed in [153], the phase shift from the $\Delta-Y$ configuration can decrease the gain of the open-loop system by $62 \%$ compared with the Y-Y configuration-based system.

3) Classification according to power circuit configuration: This section presents a review of various MFI configurations. a) Multilevel MFI (MFI-ML): In medium-voltage and high-power applications, multilevel inverter technology is a

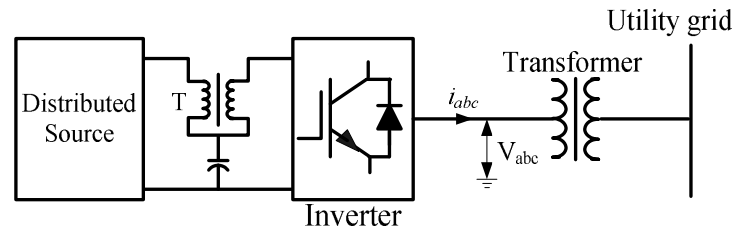

Fig. 11. Configuration of a TSI-based MFI.

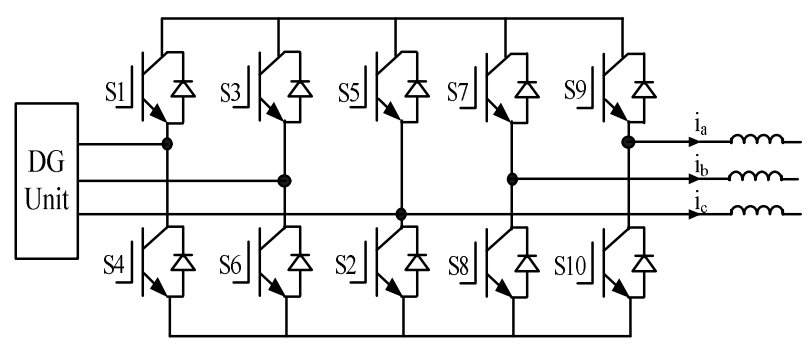

Fig. 12. Configuration of the five-leg converter.

very efficient alternative in the interfacing system for the integration of RES into the AC grid and also for other applications where high-quality voltages and currents are required. Superior harmonic spectrum, decreased voltage rating for the switches, decreased common mode voltages, and minimal voltage changes $(\mathrm{dv} / \mathrm{dt})$ are important advantages of multilevel inverters. However, the complexity of the control method is higher compared with that in the traditional two-level inverter. Basically, multilevel MFI can be classified into (1) voltage-source multilevel MFI, (2) current-source multilevel MFI, and (3) Z-source multilevel MFI.

Voltage-Source Multilevel MFI (MFI-VM): In this section, the classification of voltage-source multilevel MFI (referred to as MFI-VM in this study) is discussed.

Diode-Clamped MFI (MFI-DC): The circuit scheme of a three-phase, three-level, diode-clamped inverter is provided in Fig. 13. This scheme is utilized to integrate DG to the utility grid to improve PQ at PCC [86], [154], [155]. Each phase of the three-phase inverter employs a common DC bus subdivided into three levels by two capacitors. The voltage in each capacitor is $\mathrm{V}_{\mathrm{dc}} / 2$ and the voltage stress on each switch is restricted to $V_{d c} / 2$ through the clamping diodes. Fig. 14 shows the three-level neutral point clamped (NPC) inverter topology [156]-[165]. Each of the three legs can provide one additional output voltage level. The neutral point voltage that corresponds to one half of the DC link voltage is available at the output of the phases when appropriate diodes are clamped. Moreover, five-level NPC is used to connect DG to the AC grid [166].

Flying Capacitor MFI (MFI-FC): The three-phase, three-level, flying capacitor inverter topology is used to integrate DG to the utility grid as shown in Fig. 15 [165]. Each phase leg of the inverter has a configuration identical to that of common DC series capacitors. The inner-loop capacitors are independent in the A, B, and C phase legs. The 


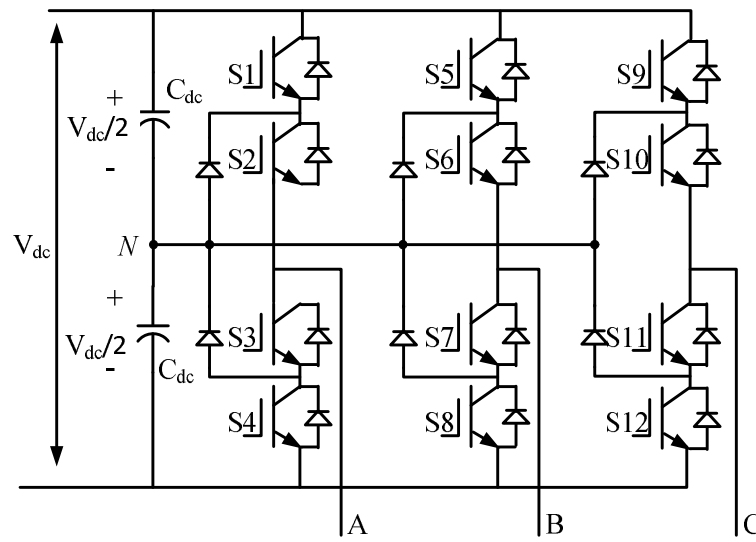

Fig. 13. Configuration of the three-level MFI-DC system.

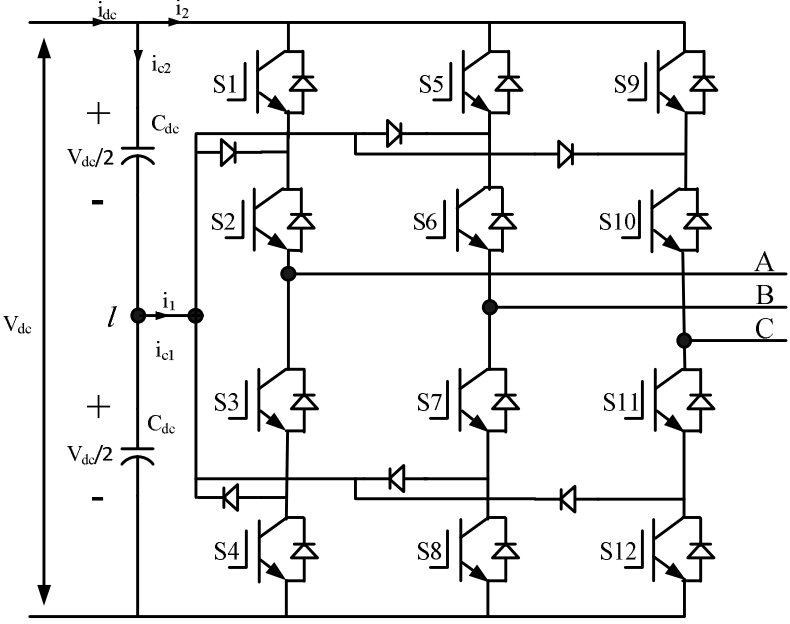

Fig. 14. Configuration of the three-level MFI-NC system.

flying capacitor multilevel inverter has the advantages of flexible switching control, high protection capability for power switches, and control of real and reactive power. The inverter requires various switching combinations to balance the voltage across the capacitor. This condition implies an increase in the complexity of the control algorithm.

Cascade H-Bridge MFI (MFI-CH): MFI-CH consists of multiple $\mathrm{H}$-bridge inverters in cascade arrangement as shown in Fig. 16. The cascade topology permits the use of DC sources with various voltage levels. High-quality and high-resolution multilevel waveforms can be obtained with a small number of components. Although the cascaded topology requires multiple isolated DC sources, the batteries or PV panels in some systems can be utilized to achieve high-efficiency transformer-less inverters. The single-phase three-level H-bridge [100], 19-level [142], and 27-level [168] cascaded H-bridge (CHB) inverters as well as the three-phase nine-level cascaded H-bridge [169] inverter are used for the integration of DG to the grid to compensate for PQ problems in PCC.

Hybrid multilevel MFI (MFI-HM): The topology of the five-level hybrid clamped inverter developed in [170] is

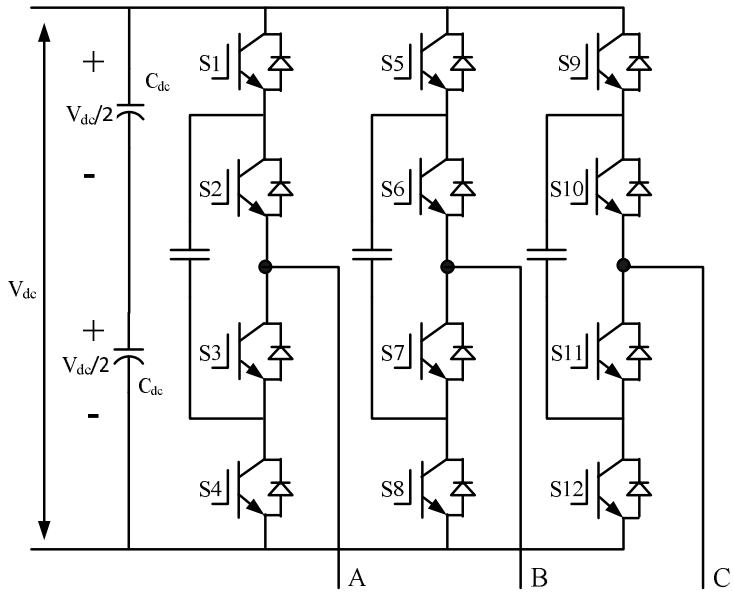

Fig. 15. Configuration of the three-level MFI-FC system.

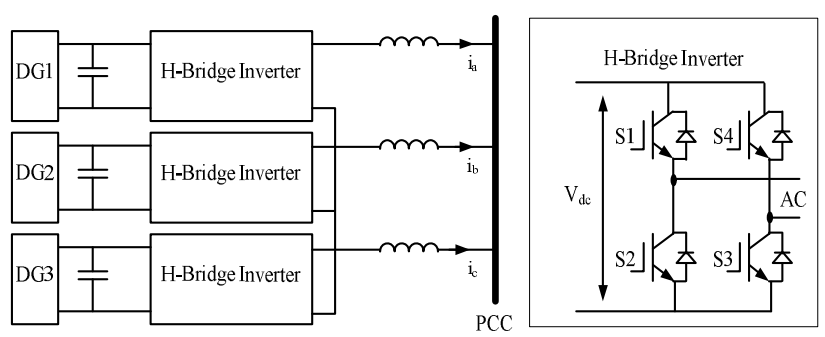

Fig. 16. Configuration of the MFI-CH system.

shown in Fig. 17. $\mathrm{V}_{\mathrm{dc}}$ represents the generator and MPPT. The hybrid clamped inverter can maintain the balanced voltages of the DC link capacitors regardless of the characteristics of the load or its operation mode. The hybrid clamped topology can control active and reactive flows regardless of the conditions of the load and has a simple arrangement that satisfies the voltage balance of the DC link capacitors. The disadvantage of the hybrid clamped topology is the number of components used. Fig. 18 shows the system configuration of the cascaded $\mathrm{NPC} / \mathrm{H}$-bridge inverter to integrate PV arrays to the utility grid. The system is comprised of two PV arrays of the same power rating, a nine-level cascaded NPC/H-bridge inverter, an LCL passive filter, and a utility grid.

The main structure of the proposed topology is comprised of two similar NPC cascaded cells. The inverter phase voltage is the sum of the output voltages of the two cascaded cells. Five different voltage output levels $\left(+2 \mathrm{~V}_{\mathrm{dc}},+\mathrm{V}_{\mathrm{dc}}, 0\right.$, $-\mathrm{V}_{\mathrm{dc}}$, and $-2 \mathrm{~V}_{\mathrm{dc}}$ ) are produced at the $\mathrm{AC}$ output terminal of the cascaded model using proper switching techniques.

The proposed topology has the following advantages: (1) MV operation improves the PQ of the currents injected into the utility grid; (2) reduction in cable size; (3) low step-up voltage is required; and (4) increased system efficiency. The configuration in [127] has the advantages of both multi-phase generators and multilevel inverters and serves as a guide to obtaining an optimum solution for multi MW rated WECS [137]. 


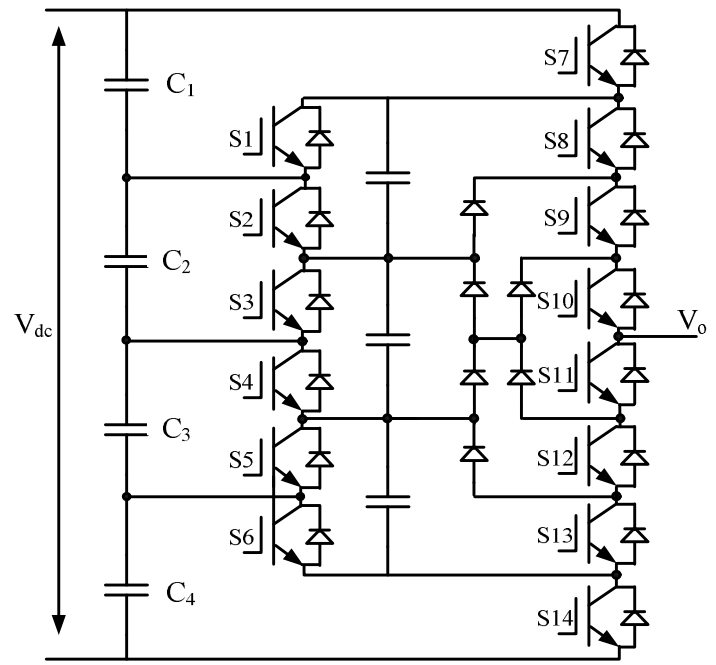

Fig. 17. Configuration of the five-level MFI-HM system.

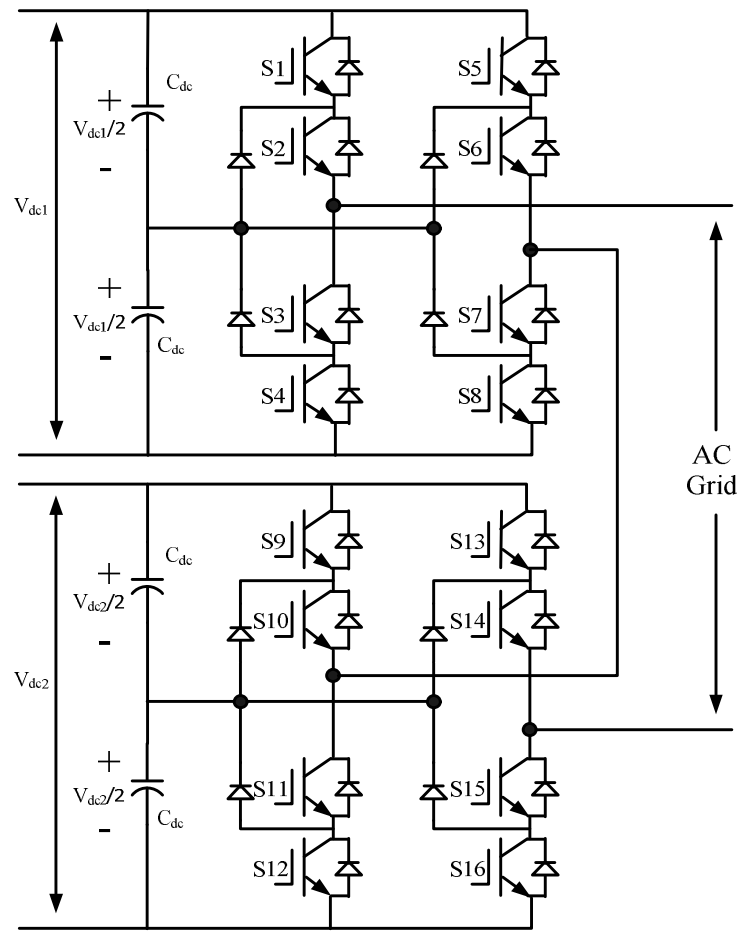

Fig. 18. Configuration of the cascaded NPC/H-bridge inverter.

Multilevel current source MFI (MFI-CM): MFI-CM allows for superior control of the current fed to the electrolyzer; thus, the level of operation is near the point of maximum efficiency. The power factor and/or harmonics can be compensated for by modifying the inverter control strategy to acquire an active power filter. The seven-level MFI-CM in [173] is used to interface the electrolyzer or fuel cell with the utility grid as shown in Fig. 20. It consists of three similar modules and has the ability to generate seven-level output current. Each module has six switching devices with bidirectional voltage blocking abilities and two inductors to maintain the balance of the currents. A capacitor bank prevents high voltages caused by

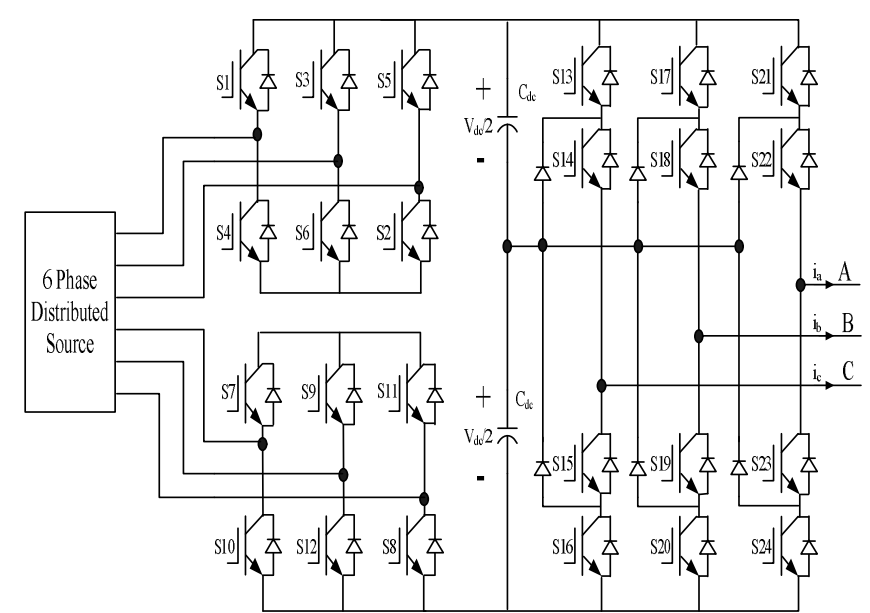

Fig. 19. Configuration of the MFI-MM system.

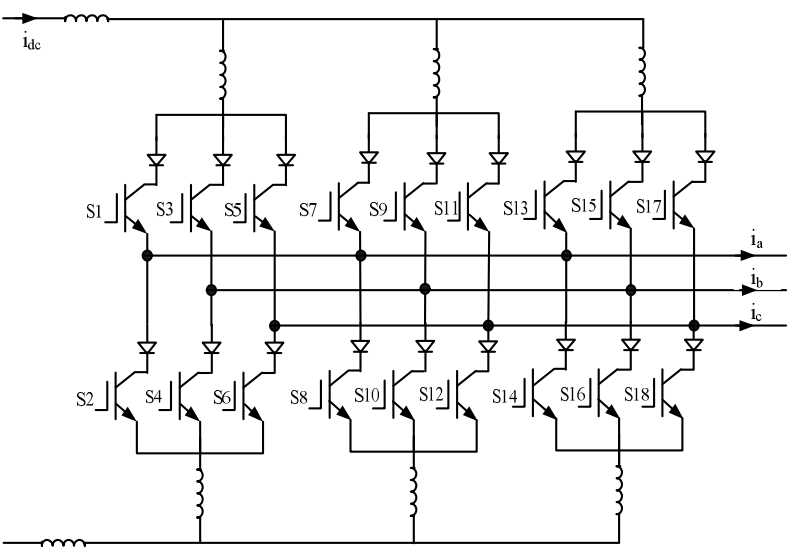

Fig. 20. Configuration of the MFI-CM system.

the commutation of the currents in the inductive loads. A phase-shifted carrier sinusoidal PWM-based control for MFI-CM is used to regulate the current in each module.

Z-source multilevel MFI (MFI-ZM): In [174], an improved interface for the utility grid connection of the PV generation systems was proposed.

The proposed topology consists of a three-level cascaded ZSI and allows for efficient, flexible, and high-quality power generation from the PV plant as shown in Fig. 21.

b) Distributed multilevel MFI (MFI-DM): In [189], an inverter system interfaced with the utility grid was proposed. The system improves the voltage quality of micro-grid applications as shown in Fig. 22. The proposed topology consists of two three-phase four-leg inverters with DG sources and linear and non-linear loads. The topology uses a series-parallel structure to construct a grid-interfacing system.

The proposed system can withstand voltage-related disturbances and maintain the power transfer between DG and the utility grid while maintaining a superior quality voltage for the customer loads. Voltage unbalance correction and harmonic current compensation functions are also achieved with MFI-DM. 
TABLE I

COMPENSATED VARIABLES USED IN MFIS

\begin{tabular}{|c|c|}
\hline Compensation Approach & Reference Number \\
\hline Reactive power & $\begin{array}{l}30,38,40,58,72,75,76,86,87,97,99,107,114, \\
115,117,129,133,137,153,154,155,157,162, \\
163,174,188,190\end{array}$ \\
\hline Current harmonics with reactive power & $\begin{array}{l}30,33,39,45,51,57,59,78,79,83,85,88,90,91, \\
94,96,100,105,106,110,113,116,119,121,128, \\
144,152,156,158,172\end{array}$ \\
\hline Voltage harmonics with reactive power & $71,73,80,82,143$ \\
\hline Current harmonics and voltages with reactive power & 98 \\
\hline Current harmonics and current unbalance with reactive power & $62,63,77,84,95,109,160,171,184,185$ \\
\hline Current harmonics, current unbalance, and neutral current with reactive power & $133,136,137,139,140,141$ \\
\hline Mitigate unbalance, harmonics, and voltage flicker with reactive power & 150 \\
\hline Current harmonics and voltage sag with reactive power & 61,167 \\
\hline Reactive power and voltage regulation & $31,67,70,148,182,183$ \\
\hline Reactive power, voltage sag, voltage ride-through, and voltage support & 60 \\
\hline Voltage harmonic and voltage unbalance with reactive power & 67,141 \\
\hline Reactive power and voltage sag and/or swell & $37,92,111,118,122$ \\
\hline Voltage control with reactive power & $32,44,186$ \\
\hline Voltage ride-through capabilities and frequency variation with reactive power & 164 \\
\hline Voltage harmonic and voltage sag with reactive power & 120 \\
\hline Fault ride-through with reactive power & 101,104 \\
\hline Regulate the PCC voltage and load unbalance with react & 130 \\
\hline
\end{tabular}

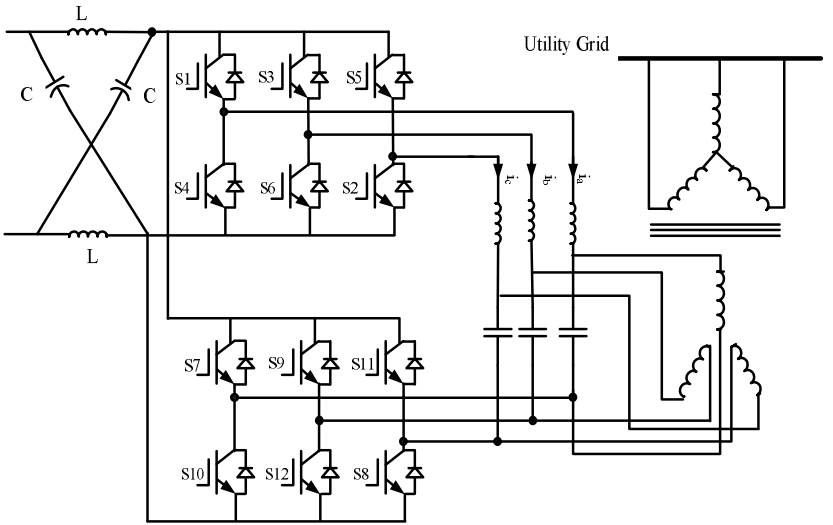

Fig. 21. The configuration of the MFI-ZM system.

\section{B. Classification Based on the Compensated Variable}

The main aim of an MFI is compensate for PQ problems (voltage quality problems, such as sags, swells, flickering, unbalance, harmonics, and current quality problems, including harmonics, reactive current, unbalance and neutral current) at the connection point of the DG sources to the utility grid. The classification of MFIs based on the compensation approach is presented in Table I.

\section{ABBREVIATIONS OF MFI CONFIGURATIONS}

Several abbreviations of MFIs based on the topology or application were described in Section II. Ten key abbreviations, namely, MFI-ML, MFI-VM, MFI-CM, MFI-ZM, MFI-DC, MFI-FC, MFI-CH, MFI-HM, MFI-MM, and MFI-DM, are presented in Table II. These abbreviations can be used to emphasize the main features of MFIs more concisely [26]. MFI-DC, MFI-FC, and MFI-CH are generally based on the VSI topology.

\section{CLASSIFICATION OF MFIS BASED ON CONTROL TECHNIQUES}

An advanced control technique is very critical for the efficient operation of power electronic-based MFI systems. MFI control techniques calculate the current and voltage reference signals and determine the switching sequence of the inverter switches. Frequency domain techniques, such as fast Fourier transform, are rarely used because of the large computation time and delay in calculating the reference signals [26]. Time domain techniques allow for the instantaneous derivation of compensating currents or voltage signals. A large number of control techniques have been successfully applied to MFIs in the time domain.

The most common time domain control methods used for MFIs are instantaneous active and reactive power (also called three-phase pq theory) [175] and synchronous reference frame (also called three-phase dq theory) methods [176]. These methods convert the current and voltage signals in the $\mathrm{ABC}$ frame into the stationary reference frame (pq theory) or the synchronously rotating frame (dq theory) to extract the fundamental and harmonic quantities [26]. Instantaneous active and reactive powers are calculated in pq theory, whereas dq theory is concerned with the free current of the source voltage. Real and reactive powers are concerned with fundamental components (pq theory). The fundamental components in the distorted voltage or current (dq theory) are DC quantities in these theories. MFI controllers based on 


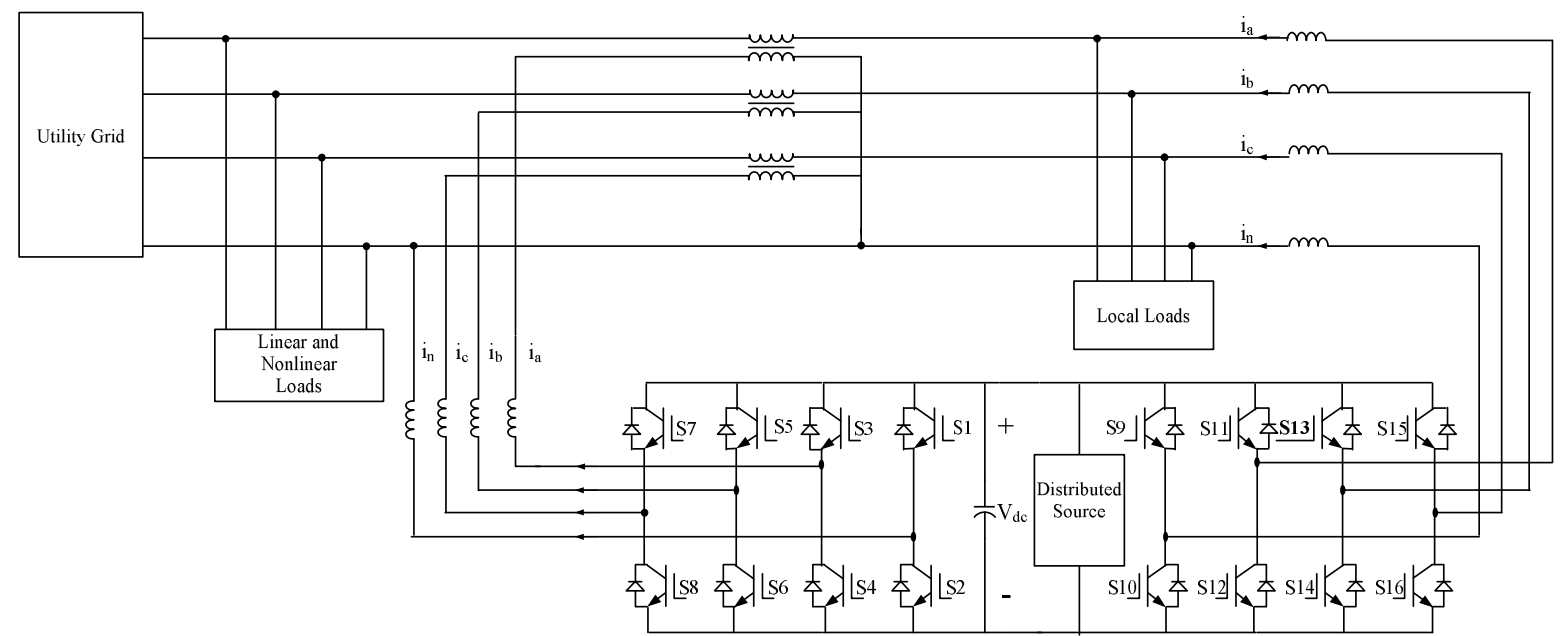

Fig. 22. Configuration of the MFI-DM system.

\section{TABLE II}

ABBREVIATIONS OF MFI CONFIGURATIONS

\begin{tabular}{ll}
\hline \hline Abbreviation & Description \\
\hline MFI-CH & Cascaded H-Bridge Multilevel MFI \\
MFI-CM & Current-Source Multilevel MFI \\
MFI-DC & Diode-Clamped Multilevel MFI \\
MFI-DM & Distributed MFI \\
MFI-FC & Flying Capacitor Multilevel MFI \\
MFI-HM & Hybrid Multilevel MFI \\
MFI-ML & Multilevel MFI \\
MFI-MM & Multiphase Multilevel MFI \\
MFI-VM & Voltage-Source Multilevel MFI \\
MFI-ZM & Z-Source Multilevel MFI \\
\hline
\end{tabular}

instantaneous active and reactive power theory were studied in [30], [60], [71], [72], [77], [78], [81], [82], [99], [100], [106], [112], [114], [133], [137], [140], [153], [177], and [178], whereas synchronously rotating frame theory-based controllers were studied in [55]-[57], [63], [65], [66], [70], [80], [82], [85], [87]-[89], [101], [103], [104], [107], [118], [120], [129], [139], [148], [150], [151], [162], [165]-[167], [174], and [179]-[182].

Synchronously rotating frame theory has limitations when the source voltages are unbalanced and/or distorted. Dq theory is modified and referred to as "dq0 theory" to eliminate these limitations as can be found in [86], [90], [113], [130], and [157]. A new adaptive linear neuron (ADALINE) technique called MO-ADALINE was implemented in multi-output (MO) systems to track or estimate the parameters and symmetrical components. The control strategy involves the use of combined fuzzy logic controller for voltage regulation and processing unit-based ADALINE for harmonics, unbalance, and reactive power compensation [63].
Moreover, a new adaptive neuro-fuzzy control method is utilized to achieve smooth bi-directional power flow and nonlinear unbalanced load compensation simultaneously; in this case, the traditional PI controller might be insufficient because of the instantaneous changes in the dynamics of the system [132], [183]. In [69], a novel integrated diagnostic system was developed for islanding detection using a neuro-fuzzy model for grid-tied inverter-based DGs. In [69], an adaptive neuro-fuzzy inference system was used for islanding detection.

In [126], a current control method for inverters based on the sigma delta modulation algorithm called the sigma delta-based current controlled voltage source inverter ( $\left.\Sigma \Delta \_C C \_V S I\right)$ interfaced with DG generators was studied. A particle swarm optimization method was used for the optimum tuning of the controllers as a result of the existent number of PI controllers. $\Sigma \Delta \Delta_{-}$CC_VSI minimizes the harmonics of the unfiltered voltage. Thus, it is powerful in minimizing electromagnetic interference, which is critical for sensitive loads [26].

The combination of methods and strategies results in diverse control concepts used in grid-connected VSCs, such as PI controller-based voltage oriented controller (PI-VOC) [111], [136], space-vector pulse width modulation (SV-PWM) and voltage oriented control (VOC) method [174], direct power control (DPC) with space vector modulation (SVM) based on sliding mode control (SMC) [97], DPC-based SVM [101], DPC strategy with non-linear SMC with and SVM [117], and DPC-EMC (electromagnetic compatibility) [73]. DC-bus voltage control has a critical role in delivering the required MFI performance. During the sudden changes in system dynamic conditions, such as instantaneous load change or voltage sag/swell, the DC-link controller responds quickly to return the DC-bus voltage to its reference point with minimum delay time and overshoot. 
The PI-based DC-link voltage controller is simple to implement and is therefore preferred by most researchers, including [30], [32], [35], [38], [39], [55], [59], [60]-[62], [67], [75], [76], [79], [81], [92], [101]-[103], [107], [116]-[118], [120], [122]-[128], [130], [134], [136], [139], [140], [145], [146], [148], [155], [157], [160], [161], [165], [167], [171], and [184]-[186].

To improve the response time of PI controller-based methods, researchers have developed several methods, including a spatial repetitive controller [128], neuro-fuzzy controller [132], [141], PI-type fuzzy logic controller [162], adaptive hysteresis band controller [78], adaptive sensorless controller [51], sliding mode controller [97], $\mathrm{H}^{\infty}$ controller [131], $\mathrm{H}^{\infty}$ repetitive controller [203], unified DC-link current controller [101], Lyapunov function-based current controller [105], fast dynamic high-performance non-linear controller [106], predictive current controller based on SV-PWM [158], and current and reactive power controllers [108]. SVM has proven to be a popular and favorable PWM scheme because of its high DC-link voltage utilization [93], [108], [110], [114], [115], [164], [169], model predictive control (MPC) [84], adaptive hysteresis controller [89, 110, 113], model-based control [111], fuzzy with hysteresis current controller [45], automatic voltage regulation [188], auto-voltage regulator designed based on discrete PID algorithm [119], and the optimal linear-adaptive regulator, which has been selected for the controller using linear-quadratic regulator control technique [158]. In [137], a stationary-frame resonant controller with direct feedback variables was utilized to arrange a dual-loop control scheme. The control methods studied in [41], [65], [73], [150], and [190] have no additional control loop for DC bus voltage regulation. The DC-link is controlled by either a current or voltage control loop.

\section{PRACTICAL STUDIES ON MFIS}

Some of the available MFIs are mainly experimental prototypes or small-scale installations whose capacities are low in general as shown in Table III. The available capacities of MFIs in single-phase are small; these MFIs are mainly implemented in PV grid-connected systems $(<4 \mathrm{kVA})$. However, the available capacities of MFIs in three-phase are usually large; these MFIs are used in wind and solar plants $(<400 \mathrm{kVA})$. The capacity of existing MFIs is small and should promote the experimental prototype for industrial applications.

Both active power flow control and compensation of PQ problems are achieved in the same MFIs in DG generators that involve the use of few power electronic components, are small, and have high efficiency, low investment cost, reduced maintenance cost, and high reliability. The reduction in investment, operation, and maintenance cost as well as the enhancement of the cost-effective features of MFIs were
TABLE III

INSTALLED CAPACITY OF MFIS

\begin{tabular}{llll}
\hline \hline Power Source & Reference & Capacity & Application \\
\hline \hline \multirow{5}{*}{ Single-phase } & {$[46]$} & $0.3 \mathrm{kVA}$ & PV \\
& {$[30]$} & $1 \mathrm{kVA}$ & PV \\
& {$[21]$} & $1 \mathrm{kVA}$ & PV \\
& {$[156]$} & $1 \mathrm{kVA}$ & PV \\
& {$[31]$} & $2 \mathrm{kVA}$ & PV \\
\hline \multirow{5}{*}{ Three-phase } & {$[148]$} & $1.2 \mathrm{~kW}$ & Fuel-Cell \\
& {$[138]$} & $2.5 \mathrm{~kW}$ & Wind \\
& {$[192]$} & $2.5 \mathrm{~kW}$ & Wind \\
& {$[196]$} & $3 \mathrm{~kW}$ & Wind \\
& {$[55]$} & $3 \mathrm{~kW}$ & PV \\
& {$[195]$} & $3.7 \mathrm{~kW}$ & Wind \\
& {$[194]$} & $11 \mathrm{~kW}$ & Wind \\
& {$[193]$} & $30 \mathrm{~kW}$ & PV \\
& & $400 \mathrm{kVA}$ & Wind \\
\hline
\end{tabular}

proposed in [77], [163], and [191].

\section{CONCLUSIONS}

This paper presented an exhaustive review of the MFIs utilized to improve the power quality in the utility grid and at consumer level. The review and classification of published articles show that MFIs can help mitigate both current- and voltage-related PQ disturbances. The latest developments in grid-tied inverters fed by RES-based DGs (i.e., PV and/or wind systems) have introduced new regulations and standards to enhance PQ. The development of new control strategies and execution of multifunctional compensation capability are the main research trends related to both active power flow control and mitigation of various PQ disturbances using MFIs. The different aspects of MFIs and the new developments in this field of research were discussed in detail in this study.

MFI-based DG systems are essential to future utility grids for the delivery of high-quality, reliable, and efficient electricity supply. To achieve this goal, various multi-level topologies and structures should be employed to increase the size of installed MFIs. The classification of MFIs will help researchers, users, and suppliers of electrical power to acquire an overview for further research and studies on this subject.

\section{REFERENCES}

[1] J. Arai, K. Iba, T. Funabashi, Y. Nakanishi, K. Koyanagi, and R. Yokoyama, "Power electronics and its applications to renewable energy in Japan," IEEE Circ. Sys. Mag., Vol. 8, No. 3, pp. 52-66, Aug. 2008.

[2] J.J. Justo, F. Mwasilu, J. Lee, and J.W. Jung, "AC-microgrids versus DC-microgrids with distributed energy resources: A review," Renewable and Sustainable Energy Reviews, Vol. 24, pp. 387-405, Aug. 2013. 
[3] M.F. Akorede, H. Hizam, I. Aris, M.Z.A. and Ab Kadir, "A critical review of strategies for optimal allocation of distributed generation units in electric power systems," IREE, Vol. 5. No. 2, pp. 593-600, Apr. 2010.

[4] P. Bhusal, A. Zahnd, M. Eloholma, and L. Halonen, "Energy-efficient innovative lighting and energy supply solutions in developing countries," IREE, Vol. 2. No. 1, pp. 665-670, Oct. 2007.

[5] H. Laaksonen and A. Mohamed, "Stability of microgrid with different configurations after islanding due to fault in the utility grid," IREE, Vol. 3. No. 3, pp. 498-512, May 2008.

[6] A. A. Salam, G. Barakat, M. A. Hannanand, and H. Shareef, "An improved inverter control scheme for managing the distributed generation units in a microgrid," IREE, Vol. 5. No. 5, pp. 891-899, May 2010.

[7] R. Belfkira, G. Barakat, and C. Nichita, "Sizing optimization of a stand-alone hybrid power supply unit: Wind/PV system with battery storage," IREE, Vol. 3. No. 5, pp. 820-828, Oct. 2008.

[8] S. Mazumder, R. Burra, R. Huang, M. Tahir, and K. Acharya, "Universal grid-connected fuel-cell inverter for residential application," IEEE Trans. Ind. Electron., Vol. 57, No. 10, pp. 3431-3447, Oct. 2010.

[9] T. A. Nergaard, J. F. Ferrell, L. G. Leslie, and J. S. Lai, "Design considerations for a $48 \mathrm{~V}$ fuel cell to split single phase inverter system with ultracapacitor energy storage," IEEE Conf. Power Electr. Spec., pp. 2007-2012, 2002.

[10] J. Selvaraj and N. A. Rahim, "Multilevel inverter for grid-connected PV system employing digital PI controller," IEEE Trans. Ind. Electron., Vol. 56, No. 1, pp. 149-158, Jan. 2009.

[11] H. Patel and V. Agarwal, "MPPT scheme for a PV-fed single-phase single-stage grid-connected inverter operating in CCM with only one current sensor," IEEE Trans. Energy Convers., Vol. 24, No. 1, pp. 256-263, Mar. 2009.

[12] Y. Jia, Z. Yang, and B. Cao, "A new maximum power point tracking control scheme for wind generation," IEEE Power System Tech. Conf., pp. 144-148, 2002.

[13] R. C. Dugan, M. F. McGranaghan, and H. W. Beaty, Electrical Power Systems Quality, McGraw-Hill, 1996.

[14] C. Sankaran, Power Quality, Boca Raton, CRC Press, 2002.

[15] IEEE recommended practices and requirements for harmonic control in electrical power systems, IEEE Standard 519-1992, 1992.

[16] IEEE standard for interconnecting distributed resources with electric power systems, IEEE Standard 1547-2003, 2003.

[17] N. G. Hingorani and L. Gyugyi, Understanding FACTS: Concepts and Technology of Flexible AC Transmission Systems, IEEE Press, 2000.

[18] V. K. Sood, HVDC and FACTS Controllers - Applications of Static Converters in Power Systems, Kluwer, 2004.

[19] A. Ghosh and G. Ledwich, Power quality enhancement using custom power devices, Kluwer, 2002.

[20] J. F. G. Cobben, W. L. Kling, and J. M. A. Myrzik, "Power quality aspects of a future micro grid," in Proc. the IEEE Int. Conf. Future Power Sys., pp. 1-5, 2005,

[21] J. H. R. Enslin and P. J. M. Heskes, "Harmonic interaction between a large number of distributed power inverters and the distribution network," IEEE Trans. Power Electron., Vol.19, No. 6, pp. 1586-1593, Nov. 2004.

[22] M. H. Bollen and F. Hassan, Integration of Distributed Generation in the Power System, Wiley-IEEE Press, 2011.
[23] A. Salarvand, B. Mirzaeian, and M. Moallem, "Obtaining a quantitative index for power quality evaluation in competitive electricity market," IET Gener. Trans. Distr., Vol. 4, No. 7, pp. 810-823, Jul. 2010.

[24] A. A. Kumar and J.S. Rao, "Power quality improvement of grid interconnected 3-phase 4-wire distribution system using fuzzy logic control," IJERT, Vol. 1, No. 4, pp. 1-5, Jun. 2012.

[25] T. T. Ma, "Power quality enhancement in micro-grids using multifunctional DG inverters," in Proc. Int. Multi Conf. of Eng., Vol. 2, 2012.

[26] V. Khadkikar, "Enhancing electric power quality using UPQC: A comprehensive overview," IEEE Trans. Power Electron., Vol. 27, No. 5, pp. 2284-2297, May 2012.

[27] V. C. Gungor, D. Sahin, T. Kocak, S. Ergut, C. Buccella, C. Cecati, and G. P. Hancke, "Smart grid technologies: Communication technologies and standards," IEEE Trans. Ind. Informat., Vol. 7, No. 4, pp. 529-539, Nov. 2011.

[28] M .A. Rahman, E. Al-Shaer, and P. A. Bera, "Noninvasive threat analyzer for advanced metering infrastructure in smart grid," IEEE Trans. Smart Grid, Vol. 4, No. 1, pp. 273-287, Mar. 2013.

[29] N. Liu, J. Chen, L. Zhu, J. Zhang, and Y. He, "A key management scheme for secure communications of advanced metering infrastructure in smart grid," IEEE Trans. Ind. Electron., Vol. 60, No. 10, Oct. 2013.

[30] K. J. P. Macken, K. Vanthournout, J. V. Keybus, G. Deconinck, and R. J. M. Belmans, "Distributed control of renewable generation units with integrated active filter," IEEE Trans. Power Electr., Vol. 19, No. 5, pp. 1353-1360, Sep. 2004.

[31] H. Alatrash, A. Mensah, E. Mark, G. Haddad, and J. Enslin, "Generator emulation controls for photovoltaic inverters," IEEE Trans. Smart Grid, Vol. 3, No. 2, pp. 996-1011, Jun. 2012.

[32] H. Kim, T. Yu, and S. Choi, "Indirect current control algorithm for utility interactive inverters in distributed generation systems," IEEE Trans. Power Electron., Vol. 23, No. 3, pp. 1342-1347, May 2008.

[33] S. H. Ko, S. R. Lee, H. Dehbonei, and C. V. Nayar, "Application of voltage and current-controlled voltage source inverters for distributed generation systems," IEEE Trans. Energy Convers., Vol. 21, No. 3, pp. 782-792, Sep. 2006.

[34] H. R. J. Enslin and J. M. P. Heskes, "Harmonic interaction between a large number of distributed power inverters and the distribution network," IEEE Trans. Power Electron., Vol. 19, No. 6, pp. 1586-1593, Nov. 2004.

[35] C.L. Trujillo, D. Velasco, E. Figueres, and G. Garcerá, "Analysis of active islanding detection methods for grid-connected micro inverters for renewable energy processing," Appl. Energy, Vol. 87, No. 11, pp. 3591-3605, Nov. 2010.

[36] B. Renders, K. De Gusseme, W. R. Ryckaert, and L. Vandevelde, "Converter-connected distributed generation units with integrated harmonic voltage damping and harmonic current compensation function," Electric Power Sys. Res., Vol. 79, No. 1, pp. 70, Jan. 2009.

[37] S. Goyal, A. Ghosh, and G. Ledwich, "Active power flow control in a distribution system using discontinuous voltage controller," Electric Power Sys. Res., Vol. 79, No. 1, pp. 255-264, Jan. 2009.

[38] L. Hassaine, E. Olias, J. Quintero, and M. Haddadi, "Digital power factor control and reactive power regulation for 
grid-connected photovoltaic inverter," Ren. Energy, Vol 34, No. 1, pp. 315-321, Jan. 2009.

[39] E. K. Hussain, C. M Bingham, and D. Stone, "Grid connected PVs \& Wind turbine with a wide range of reactive power control and active filter capability," IEEE Int. Conf. Inn. Smart Grid Tech., pp. 1-6, 5-7, 2011.

[40] C. Wen, G. Lu, P. Wang, Z. Li, X. Liu, and Z. Fan, "Vector control strategy for small-scale grid connected PMSG wind turbine converter," $2^{\text {nd }}$ IEEE Int. Conf. Inn. Smart Grid Tech., pp. 1-7, Dec. 2011.

[41] S. Jena, B. C. Babu, N. K. Naik, and G.Mishra, "Performance improvement of single-phase grid-connected PWM inverter using PI with hysteresis current controller," IEEE Int. Conf. Energy, Auto. Sig., pp. 1-5, Dec. 2011.

[42] R. Shao, M. Kaye, and L. Chang, "Advanced building blocks of power converters for renewable energy based distributed generators," $8^{\text {nd }}$ IEEE Int. Conf. Power Electr., pp. 2168-2174, May/Jun. 2011.

[43] G. Ramai, T. Tran-Quoc, and N. Hadjsaid, "Fuzzy logic, supervision and control of distributed generators," $18^{\text {th }}$ Int.Conf. Exh. Elec. Distr., pp. 1-5, 6-9 June 2005.

[44] T. L. Vandoorn, C. M. Ionescu, J. D. M. De Kooning, R. De Keyser, and L. Vandevelde, "Theoretical analysis and experimental validation of single-phase direct versus cascade voltage control in islanded microgrids," IEEE Trans. Ind. Electron., Vol. 60, No. 2, pp. 789-798, Feb. 2013.

[45] S. Jena and B.C. Babu, "Power quality improvement of 1-Ф grid-connected PWM inverter using fuzzy with hysteresis current controller," IEEE $10^{\text {th }}$ Int. Conf. Env. Elec. Eng., pp. 1-4, 8-11 May 2011.

[46] A. Yafaoui, B. Wu, and S. Kouro, "Improved active frequency drift anti-islanding method with lower total harmonic distortion," IEEE $36^{\text {th }}$ Annu. Conf. Ind. Elec. Soc., pp. 3216-3221, 2010.

[47] I. Serban and C. Marinescu, "Active power decoupling circuit for a single-phase battery energy storage system dedicated to autonomous microgrids," IEEE Int. Symp. Ind. Elec., pp. 2717-2722, 4-7 Jul. 2010

[48] P. Neves, D. Gonçalves, J. G. Pinto, R. Alves, and J. L. Afonso, "Single phase shunt active filter interfacing renewable energy sources with the power grid," IEEE $35^{\text {th }}$ Annu. Conf. Ind. Elec., pp. 3264-3269, Nov. 2009.

[49] G. Buticchi, D. Barater, E. Lorenzani, and G. Franceschini, "Digital control of actual grid-connected converters for ground leakage current reduction in PV transformerless systems," IEEE Trans. Ind. Inf., Vol. 8, No. 3, pp. 563-572, Aug. 2012.

[50] B. R. Lin and J. Ji Chen, "Three-phase two-leg inverter for stand-alone and grid-connected renewable energy systems," IEEE Region 10 Conf., pp. 1-4, 2006.

[51] C. Picardi, D. Sgrò, and G. Gioffré, "A new active filtering technique for grid-connected inverters," IEEE Inte. Symp. Power Elect., Elec. Dri., Autom. Moti., pp. 900-905, 2012.

[52] K.H. Ahmed, A.M. Massoud, S.J. Finney, and B.W. Williams, "Autonomous adaptive sensorless controller of inverter based islanded distributed generation system," IET Power Electr., Vol. 2, No. 3, pp. 256-266, May 2009.

[53] P. Antoniewicz and M. P. Kazmierkowski, "Virtual flux based predictive direct power control of ac/dc converters with online inductance estimation," IEEE Tran. Ind. Electron., Vol. 55, No. 12, pp. 4381-4390, Dec. 2008.

[54] Q. Zeng and L. Chang, "An advanced SVPWM-based predictive current controller for three-phase inverters in distributed generation systems," IEEE Tran. Ind. Electron., Vol. 55, No. 3, pp. 1235-1246, Mar. 2008.

[55] R. Teodorescu and F. Blaabjerg, "Flexible control of small wind turbines with grid failure detection operating in stand-alone and grid-connected mode," IEEE Tran. Power Electron., Vol. 19, No. 5, pp. 1323-1332, Sep. 2004.

[56] Y. Abdel and R. I. "Mitigation of converter-grid resonance, grid-induced distortion, and parametric instabilities in converter-based distributed generation," IEEE Tran. Power Electron., Vol. 26, No. 3, pp. 983-996, Mar. 2011.

[57] S. Dasgupta, S. N. Mohan, S. K. Sahoo, and S. K. Panda, "Lyapunov function-based current controller to control active and reactive power flow from a renewable energy source to a generalized three-phase microgrid system," IEEE Tran. Ind. Electron., Vol. 60, No. 2, pp. 799-813, Feb. 2013.

[58] F. Delfino, R. Procopio, M. Rossi, and G. Ronda, "Integration of large-size photovoltaic systems into the distribution grids: A P-Q chart approach to assess reactive support capability," IET Ren. Power Gener., Vol. 4, No. 4, pp. 329-340, Jul. 2010.

[59] M. Singh, V. Khadkikar, and A. Chandra, "Grid synchronization with harmonics and reactive power compensation capability of a permanent magnet synchronous generator-based variable speed wind energy conversion system," IET Power Electr., Vol. 4, No. 1, pp. 122-130, Jan. 2011

[60] A. Camacho, M. Castilla, J. Miret, J. C. Vasquez, and E. Alarcón-Gallo, "Flexible voltage support control for three-phase distributed generation inverters under grid fault," IEEE Trans. Ind. Electron., Vol. 60, No. 4, pp. 1429-1441, Apr. 2013

[61] M. P. Kazmierkowski, M. Jasinski, and G. Wrona, "DSP-based control of grid-connected power converters operating under grid distortions," IEEE Trans. Ind. Informat., Vol. 7, No. 2, pp. 204-211, May 2011.

[62] X. Tang, K. M. Tsang, and W. L. Chan, "A power quality compensator with DG interface capability using repetitive control," IEEE Trans. Energy Convers., Vol. 27, No. 2, pp. 213-219, Jun. 2012.

[63] M. I. Marei, E. F. El-Saadany, and M. M. A. Salama, "A novel control algorithm for the DG interface to mitigate power quality problems," IEEE Trans. Power Del., Vol. 19, No. 3, pp. 1384-1392, Jul. 2004.

[64] J. He, Y. W. Li, and M. S. Munir, "A flexible harmonic control approach through voltage-controlled DG-grid interfacing converters," IEEE Trans. Ind. Electron., Vol. 59, No. 1, pp. 444-455, Jan. 2012.

[65] M. A. Zamani, A. Yazdani, and T. S. Sidhu, "A control strategy for enhanced operation of inverter-based microgrids under transient disturbances and network faults," IEEE Trans. Power Del., Vol. 27, No. 4, pp. 1737-1747, Oct. 2012

[66] E. Pouresmaeil, D. M. Miracle, O. G. Bellmunt, and J. B. Jané, "A multi-objective control strategy for grid connection of DG (distributed generation) resources," Energy, Vol. 35, No. 12, pp. 5022-5030, Dec. 2010.

[67] S. Li, T. A. Haskew, Y. K. Hong, and L. Xu, "Direct-current vector control of three-phase grid-connected rectifier-inverter," Electric Power Sys. Res., Vol. 81, No. 2, pp. 357-366, Feb. 2011.

[68] L. Gidwani, H. Tiwari, and R.C. Bansal, "Improving power quality of wind energy conversion system with unconventional power electronic interface," Int. Jour. of 
Elec. Power \& Energy Sys., Vol. 44, No. 1, pp. 445-453, Jan. 2013.

[69] F. Hashemi, N. Ghadimi, and B. Sobhani, "Islanding detection for inverter-based DG coupled with using an adaptive neuro-fuzzy inference system," Int. Jour. Elec. Power \& Energy Sys., Vol. 45, No. 1, pp. 443-455, Feb. 2013.

[70] C. He, X. Xie, H. Yan, C. Xie, and G. Chen, "A novel grid-connected converter with active power filtering function," Energy Proc., Vol. 12, pp. 348-354, 2011.

[71] M. Savaghebi, J. C. Vasquez, A. Jalilian, J. M. Guerrerob, and T. L. Lee, "Selective compensation of voltage harmonics in grid-connected microgrids," Math. Comp. Simu., Vol. 91, pp. 211-228, May 2013.

[72] G. Tsengenes and G. Adamidis, "Investigation of the behavior of a three phase grid-connected photovoltaic system to control active and reactive power," Elec. Power Sys. Res., Vol. 81, No. 1, pp. 177-184, Jan. 2011.

[73] M. Cirrincione, M. Pucci, and G. Vitale, "Direct power control of three-phase VSIs for the minimization of common-mode emissions in distributed generation systems," Elec. Power Sys. Res., Vol. 81, No. 4, pp. 830-839, Apr. 2011.

[74] A. M. Eltamaly, "A novel harmonic reduction technique for controlled converter by third harmonic current injection," Elec. Power Sys. Res., Vol. 91, pp. 104-112, Oct. 2012.

[75] M. Chinchilla, S. Arnalte, J.C. Burgos, and J.L. Rodrı'guez, "Power limits of grid-connected modern wind energy systems," Ren. Energy, Vol. 31, No. 9, pp. 1455-1470, Jul. 2006.

[76] S. W. Mohoda, S. M. Hatwara, and M. V. Awareb, "Grid support with variable speed wind energy system and battery storage for power quality," Energy Proc., Vol. 12, pp. 1032-1041, 2011.

[77] Z. Chen, F. Blaabjerg, and J. K. Pedersen, "A multi-functional power electronic converter in distributed generation power systems," IEEE $36^{\text {th }}$ Conf. Power Electr., pp. 1738-1744, 2005.

[78] Y. Mosazadeh, H. Fathi, A.R.Sheykholeslami, and M. Hajizadeh, "Adaptive hysteresis band controlled grid connected PV system with active filter function," IEEE Conf. Power Eng. Ren. Energy, pp. 1-6, 2012.

[79] E. Pouresmaeil, C. Miguel-Espinar, M. Massot-Campos, D. Montesinos-Miracle, O. Gomis-Bellmunt, "A control technique for integration of DG units to the electrical networks," IEEE Trans.Ind. Electr., Vol. 60, No. 7, pp. 2881-2893, Jul. 2013.

[80] M. T. Dehghani, A. Vahedi, M. Savaghebi, and J. M. Ouerrero, "Voltage quality improvement in islanded microgrids supplying nonlinear loads," IEEE Conf. Power Electr. Drive Syst. Tech., pp. 360-365, 2012.

[81] S. Eren, A. Bakhshai, and P. Jain, "Control of grid-connected voltage source inverter with LCL filter," IEEE Annu. Conf. Appl. Power Electr., pp. 1516-1520, 2012.

[82] M. Savaghebi, J. M. Guerrero, A. Jalilian, J. C. Vasquez, and T. L. Lee, "Hierarchical control scheme for voltage harmonics compensation in an islanded droop-controlled microgrid," IEEE $9^{\text {th }}$ Int. Conf. Power Electr. Drive Sys., pp. 89-94, 2011.

[83] K. Ilango, P. V. Manitha, and G. N. Manjula, "An enhanced controlled for shunt active filter interfacing renewable energy source and grid," IEEE $5^{\text {th }}$ Int. Conf. Power Electr., pp. 1-5, 2012.
[84] T. S. Hwang, S. Y.Park, and S. Gupta, "Distributed model predictive control of multi-functional power conditioning system for building energy efficiency," IEEE Conf. Energy Convers., pp. 2751-2758, 2012.

[85] V. Khadkikar, R. K Varma, and R. Seethapathy, "Impact of distributed generation penetration on grid current harmonics considering non-linear loads," IEEE $3^{\text {th }}$ Int. Conf. Power Electr. Distr. Gener. Sys., pp. 608-614, 2012.

[86] S.Huseinbegovic, B.Perunicic, C. Milosavljevic, and B. Veselic, "Direct power control for various topologies of three phase grid-connected voltage sources converters using sliding mode control," IEEE Int. Conf. Ind. Tech., pp. 795-801, 2012.

[87] S. Dasgupta, S. N. Mohan, S. K. Sahoo, and S. K. Panda, "Evaluation of current reference generation methods for a three-phase inverter interfacing renewable energy sources to generalized micro-grid," IEEE $9^{\text {th }}$ Int. Conf. Power Electr. Drive Sys., pp. 316- 321, 2011.

[88] G. Mehta, S. P. Singh, and R. D. Patidar, "Non-linear load compensation in Fuel Cell grid interfaced system using active power filter," IEEE $9^{\text {th }}$ Int. Conf. Power Electr. Drive Sys., pp. 197-202, 2011.

[89] S. Jena, B.C. Babu, G. Mishra, and A. K. Naik, "Reactive power compensation in inverter-interfaced distributed generation," IEEE Int. Conf. Energy, Auto. Sig., pp. 1-6, 2011.

[90] S. Jena, B. C. Babu, and A. Naik, "Experimental study on reactive power management in inverter-interfaced distributed generation system," IET Int. Conf. Sust. Energy Intell.Sys., pp. 80-85, 2011.

[91] T. Nouri and S. Ghasemzadeh, "A new flexible distributed generation unit for active power generation and harmonic compensation under non-ideal source voltages condition," IEEE $7^{\text {th }}$ Int. Conf. Elec. Electr. Eng., pp. 263-267, 2011.

[92] B. C.Wang, X. O. Guo, Xi. K. Huang, and W. Y. Wu, "Flexible control of three-phase distributed generation systems for voltage rise mitigation in microgrid," Przeglad Elektrotechniczny (Electrical Review), 7b/2012.

[93] W.Al-Saedi, S. W. Lachowicz, and D. Habibi, "An optimal current control strategy for a three-phase grid-connected photovoltaic system using particle swarm optimization," IEEE Conf. Power Eng. Auto., pp. 286-290, 2011.

[94] V. Vekhande and B. G. Fernandes, "Bidirectional current-fed converter for integration of DC micro-grid with AC grid," IEEE Annu. Conf., pp. 1-5, 2011.

[95] A. Hamadi, S. Rahmani, K. Al-Haddad, and Y.A. Al-Turki, "A three-phase three wire grid-connect photovoltaic energy source with sepic converter to track the maximum power point," IEEE $37^{\text {th }}$ Annu. Conf. Ind. Electr. Soc., pp. 3087-3092, 2011.

[96] S. Dasgupta, S. N. Mohan, S. K. Sahoo, and S. K. Panda, "A FBD theory based grid frequency independent current reference generation method for a three phase inverter interfacing renewable energy sources to generalized micro-grid," IEEE $37^{\text {th }}$ Annu. Conf. Ind. Electr. Soc., pp. 3076-3081, 2011.

[97] L. Xiao, S. Huang, L. Zheng, Q. Xu, and K. Huang, "Sliding mode SVM-DPC for grid-side converter of D-PMSG under asymmetrical faults," IEEE Int. Conf. Electr. Mach. Sys., pp. 1-6, 2011.

[98] A. G. Agamy, A.H. K. Alaboudy, H. E. Mostafa, and M.Y. Fekry, "Bacterial foraging-based PI controller of inverter-based distributed generators," IEEE Conf. PowerTech, pp. 1-7, 2011. 
[99] L. Su, G. Li, Z. Jin, "Modeling, control and testing of a voltage source inverter based microgrid," IEEE $14^{\text {th }}$ Int. Conf. Elec. Utility Dereg. Restru. Power Tech., pp. 724-729, 2011.

[100]E. Pouresmaeil, D. M. Miracle, and O. G. Bellmunt, "Control scheme of three-level H-bridge converter for interfacing between renewable energy resources and AC grid," 14 $4^{\text {th }}$ Euro. Conf. Power Electr. Appl., pp. 1-9, 2011.

[101]J. Dai, D. Xu, B. Wu, and N. R. Zargari, "Unified DC-link current control for low-voltage ride-through in current-source-converter-based wind energy conversion systems," IEEE Trans. Power Electron., Vol. 26, No. 1, pp. 288-297, Jan. 2011.

[102]J. Dai, D. Xu, and B. Wu, "A novel control scheme for current-source-converter-based PMSG wind energy conversion systems," IEEE Trans. Power Electron., Vol. 24, No. 4, pp. 963-972, Apr. 2009.

[103]X. Liu, P. C. Loh, P. Wang, and F. Blaabjerg, "A direct power conversion topology for grid integration of hybrid AC/DC energy resources," IEEE Trans. Ind. Electron., Vol. 60, No. 12, pp. 5696-5707, Dec. 2013.

[104]M. Popat, B. Wu, and N. R. Zargari, "Fault ride-through capability of cascaded current-source converter-based offshore wind farm," IEEE Trans. Sust. Energy, Vol. 4, No. 2, Apr. 2013.

[105]S. Dasgupta, S. N. Mohan, S. K. Sahoo, and S. K. Panda, "A Lyapunov function based current controller to control active and reactive power flow in a three phase grid connected PV inverter under generalized grid voltage conditions," IEEE $8^{\text {th }}$ Int. Conf. Power Electr., pp. 1110-1117, 2011.

[106]S. Dasgupta, S. N. Mohan, S. K. Sahoo, and S. K. Panda, "Derivation of instantaneous current references for three phase PV Inverter connected to grid with active and reactive power flow control," IEEE $8^{\text {th }}$ Int. Conf. Power Electr., pp. 1228-1235, 2011.

[107]K.M. Abo-Al-Ez, X. Xia, and J. Zhang, "Smart interconnection of a PV/Wind DG micro grid with the utility distribution network," IEEE $9^{\text {th }}$ Conf. Ind. Commer. Energy, pp. 1-8, 2012.

[108]K. Mahendran, B. Indhumath, Dr. S.u. Prabha, and S. Suryakala, "Adapted SVPWM for T-source inverter for renewable energy system," IEEE Int. Conf. Comp., Electr. Elec. Tech., pp. 404-408, 2012.

[109]M. Goyal and R. Gupta, "Power flow control in distributed microgrid with wind energy system," IEEE Student Conf. Eng. Sys., pp. 1-5, 2012.

[110]S. Jena, B. C. Babu, S.R. Samantaray, and M. Mohapatra, "Comparative study between adaptive hysteresis and SVPWM current control for grid-connected inverter system," IEEE Students' Tech. Symp., 2011.

[111]E. Paál, Z. Weitzl, and C. S. Choi, "Grid management functions built in PV inverters for distributed power generation," IEEE $8^{\text {th }}$ Int. Conf. Power Electr., pp. 2637-2644, 2011.

[112]J. C. Vasquez, J. M. Guerrero, M. Savaghebi, and R. Teodorescu, "Modeling, analysis, and design of stationary reference frame droop controlled parallel three-phase voltage source inverters," IEEE $8^{\text {th }}$ Int. Conf. Power Electr., pp. 272-279, 2011.

[113]B. C. Babu, M. Mohapatra, S. Jena, and A. Naik, "Dynamic performance of adaptive hysteresis current controller for mains-connected inverter system," IEEE Int. Conf. Ind. Electr., Cont. Rob., pp. 95-100, 2010.
[114]G. A. Tsengenes and G. A. Adamidis, "Study of a simple control strategy for grid connected VSI using SVPWM and p-q theory," XIX Conf, Elec. Mach, pp. 1-6, 2010.

[115]J. Zhao and J. Jiang, "Implementation of grid-connected power conditioner for renewable energy," IEEE Int. Conf. Power Electr. Moti. Con., pp. 2497-2500, 2009.

[116]H. Bai and S. Shang, "A research of combined multifunctional three phase grid-connected inverter/active power filter for PV system," IEEE Int, Symp. Power Electr. Distr. Gener. Sys., pp. 224-228, 2010.

[117]J. Hu and B. Hu, "Direct active and reactive power regulation of grid connected voltage source converters using sliding mode control approach," IEEE Int. Symp. Ind. Electr., pp. 3877-3882, 2010.

[118]K. H. Ahmed, A. M. Massoud, S. J. Finney, and B. W. Williams, "New voltage regulation techniques for low voltage radial feed PWM inverter based distributed networks," IEEE Int. Symp. Ind. Electr., pp. 2241-2246, 2010.

[119]C. Du, C. Zhang, and A. Chen, "Amplitude limiting for the photo-voltaic (PV) grid-connected inverter with the function of active power filter," IEEE Int, Symp. Power Electr. Distr. Gener. Syst., pp. 426-432, 2010.

[120]M. P. Kazmierkowski, M. Jasinski, and M. BobrowskaRafal, "AC-DC-AC converter with grid voltage dips mitigation," $14^{\text {th }}$ Int. Conf. Power Electr. Moti. Con., pp. 69-74, 2010.

[121]M. Savaghebi and A. Jalilian, "A new control strategy for distributed generation interface converters to compensate microgrid harmonics," Int. Symp. Power Electr. Elec. Drives Auto. Moti., pp. 908-913, 2010.

[122]E. Paál and Z. Tatai, "Grid connected inverters influence on power quality of smart grid," IEEE $14^{\text {th }}$ Int. Conf. Power Electr. Moti. Con, pp. T6-35-T6-39, 2010.

[123]J. Dannehl, F. W. Fuchs, and P. B. Thøgersen, "PI state space current control of grid-connected PWM converters with LCL filters," IEEE Trans. Power Electron., Vol. 25, No. 9, pp. 2320-2330, Sep. 2010.

[124]W. Yue, C. Zhao, Y. Lu, and G. Li, "A scheme of connecting microgird to ac grid via flexible power electronics interface," Int. Conf. Power Sys. Tech., pp. 1-6, 2010.

[125]D. K. Choi, D. H. Kang, and K. B. Lee, "A novel gain scheduling method for distributed power generation systems with a LCL-filter by estimating grid impedance," IEEE Int. Symp. Ind. Electr., pp. 3438-3443, 2010.

[126]M. Davari, I. Salabeigi, G. B. Gharehpetian, S.H. Fathi, and A. Kashefi Kaviani, "Optimal tuning of multifunction current controller for sigma delta modulation inverter-based distributed generation using PSO method," IEEE Conf., pp. $1-6,2009$.

[127]M. J. Duran, S. Kouro, B. Wu, E. Levi, F. Barrero, and S. Alepuz, "Six-phase PMSG wind energy conversion system based on medium-voltage multilevel converter," $14^{\text {th }}$ Europ. Conf. Power Electr. Appl., pp. 1-10, 2011.

[128]S. Dasgupta, S. N. Mohan, S. K. Sahoo, and S. K. Panda, "Application of four switch based three phase grid connected inverter to connect renewable energy source to a generalized unbalanced microgrid system," IEEE Trans. Ind. Electron., Vol. 60, No. 3, pp. 1204-1215, Mar. 2013.

[129]M. M. Amin and O. A. Mohammed, "Development of high-performance grid-connected wind energy conversion system for optimum utilization of variable speed wind turbines," IEEE Trans. Sust. Energy, Vol. 2, No. 3, pp. 235-245, Jul. 2011 
[130]A. Elmitwally and M. Rashed, "Flexible operation strategy for an isolated PV-diesel microgrid without energy storage," IEEE Trans. Energy Convers., Vol. 26, No. 1, pp. 235-244, Mar. 2011.

[131]Q. C. Zhong, J. Liang, G. Weiss, C. Feng, and T. C. Green, " $\mathrm{H}^{\infty}$ control of the neutral point in four-wire three-phase DC-AC converters," IEEE Trans. Ind. Electron., Vol. 53, No. 5, pp. 1594-1602, Oct. 2006.

[132]M. Singh and A. Chandra, "Real-time implementation of ANFIS control for renewable interfacing inverter in 3P4W distribution network," IEEE Trans. Ind. Electron., Vol. 60, No. 1, pp. 121-128, Jan. 2013.

[133]F. Wang, J. L. Duarte, and M. A. M. Hendrix, "Pliant active and reactive power control for grid-interactive converters under unbalanced voltage dips," IEEE Trans. Power Electron., Vol. 26, No. 5, pp. 1511-1521, May 2011.

[134]M. Prodanovi'c and T. C. Green, "High-quality power generation through distributed control of a power park microgrid," IEEE Trans. Ind. Electron., Vol. 53, No. 5, pp. 1471-1482, Oct. 2006.

[135]B. Singh and S.Sharma, "Design and implementation of four-leg voltage-source-converter-based VFC for autonomous wind energy conversion system," IEEE Trans. Ind. Electron., Vol. 59, No. 12, pp. 4694-4703, Dec. 2012.

[136]M. Singh, V. Khadkikar, A. Chandra, and R. K. Varma, "Grid interconnection of renewable energy sources at the distribution level with power-quality improvement features," IEEE Trans. Power Del., Vol. 26, No. 1, pp. 307-315, Jan. 2011.

[137]F. Wang, J.L. Duarte, and M.A.M. Hendrix, "Design and analysis of active power control strategies for distributed generation inverters under unbalanced grid faults," IET Gener. Trans. Distrib., Vol. 4, No. 8, pp. 905-916, Aug. 2010.

[138]M. Singh and A. Chandra, "Application of adaptive network-based fuzzy inference system for sensorless control of PMSG-based wind turbine with nonlinear-load-compensation capabilities," IEEE Trans. Power Electr., Vol. 26, No. 1, pp. 165-175, Jan. 2011.

[139]F. Li, X. Wang, Z. Chen, X. Zhang, and Y. Hu, "A control strategy for multi-functional converter to improve grid power quality," IEEE $37^{\text {th }}$ Annu. Conf. Ind. Electr. Soc., pp. 790-795, 2011.

[140]S. Khani, L. Mohammadian, and S. H. Hosseini, "Controlling a 4-wire PV-AF system in existence of unbalanced and distorted supply voltages," $20^{\text {th }}$ Iranian Conf. Electr. Eng, pp. 473-478, 2012.

[141]Y. Ma, T. Ellinger, and J. Petzoldt, "Implementation of harmonic control for a 3-phase 4-wire inverter with harmonic-loaded neutral," $14^{\text {th }}$ Europ. Conf. Power Electr. Appl, pp. 1-10, 2011.

[142]E. Beser, B. Arifoglu, S. Camur, and E. K. Beser, "A grid-connected photovoltaic power conversion system with single-phase multilevel inverter," Solar Energy, Vol. 84, No. 12, pp. 2056-2067, Dec. 2010.

[143]C. J. Gajanayake, D. M. Vilathgamuwa, P. C. Loh, R. Teo-dorescu, and F. Blaabjerg, "Z-source-inverter-based flexible distributed generation system solution for grid power quality improvement," IEEE Trans. Energy Convers., Vol. 24, No. 3, pp. 695-704, Sep. 2009.

[144]C. J. Gajanayake, D. M. Vilathgamuwa, P. C. Loh, F. Blaabjerg, and R. Teodorescu, "A Z-source inverter based flexible DG system with p+resonance and repetitive controllers for power quality improvement of a weak grid," IEEE Conf, Power Electr., pp. 2457-2463, 2007.
[145]X. Chen, Q. Fu, and D. G. Infield, "PV grid-connected power conditioning system with Z-source network," Int. Conf. Sust. Power Gener. Sup., pp. 1-6, 2009.

[146]D. Sun, B. Ge, D. Bi, and F. Z. Peng, "Analysis and control of quasi-Z source inverter with battery for grid-connected PV system," Int. Jour. Elec. Power \& Energy Sys., Vol. 46, pp. 234-240, Mar. 2013.

[147]M. Shahbazi, P. Poure, S. Saadate, and M. R. Zolghadri, "Five-leg converter topology for wind energy conversion system with doubly fed induction generator," Ren. Energy, Vol. 36, No.11, pp. 3187-3194, Nov. 2011.

[148]S. Jain, J. Jiang, X. Huang, and S. Stevandic, "Modeling of fuel-cell-based power supply system for grid interface," IEEE Trans. Indus. Appl., Vol. 48, No. 4, pp. 1142-1153, Jul./Aug. 2012.

[149]M. Dai, M. N. Marwali, J. W. Jung, and A. Keyhani, "Power flow control of a single distributed generation unit," IEEE Trans. Power Electron., Vol. 23, No. 1, pp. 343-352, Jan. 2008.

[150]M. I. Marei, E. F. El-Saadany, and M. M. A. Salama, “A flexible DG interface based on a new rls algorithm for power quality improvement," IEEE Sys. Jour., Vol. 6, No. 1, pp. 68-75, Mar. 2012.

[151]L. A. de S. Ribeiro, O. R. Saavedra, S.. L. Lima, J. G. de Matos, and G. Bonan, "Making isolated renewable energy systems more reliable," Ren. Energy, Vol. 45, pp. 221-231, Sep. 2012.

[152]A. Andreotti, A. Del Pizzo, R. Rizzo, and P. Tricoli, "An efficient architecture of a PV plant for ancillary service supplying," Int. Symp. Power Electr. Elec. Drives Auto. Moti., pp. 678-682, 2010.

[153]H. Mahmood and J. Jiang, "Modeling and control system design of a grid connected VSC considering the effect of the interface transformer type," IEEE Trans. Smart Grid, Vol. 3 , No. 1, pp. 122-134, Mar. 2012.

[154]R. Rajarajan and P.Aravindan, "Maximum power extraction in grid connected DFIG using 3 level diode clamped inverter," Int. Conf. Computing, Electr. Elec. Tech., pp. 319-324, 2012.

[155]E. Pouresmaeil, O. G. Bellmunt, D. M. Miracle, and J. B. Jané, "Multilevel converters control for renewable energy integration to the power grid," Energy, Vol. 36, No. 2, pp. 950-963, Feb. 2011.

[156]S. Ozdemir, N. Altin, and I. Sefa, "Single stage three-level MPPT inverter for solar supplied systems," Int. Symp. Power Electr., Elec. Drives, Auto. Moti., pp. 103-108, 2012.

[157]A. Etxeberria, I. Vechiu, H. Camblong, and J.-M. Vinassa, "Comparison of three topologies and controls of a hybrid energy storage system for microgrids," Energy Convers. Manag., Vol. 54, No. 1, pp. 113-121, Feb. 2012.

[158]S. Alepuz, S. B. Monge, J. Bordonau, J. Gago, D. González, and J. Balcells, "Interfacing renewable energy sources to the utility grid using a three-level inverter," IEEE Trans. Ind. Electron., Vol. 53, No. 5, pp. 1504-1511, Oct. 2006.

[159]E. Pouresmaeil, D. M. Miracle, and O. G. Bellmunt, "Control scheme of three-level NPC inverter for integration of renewable energy resources into AC grid," IEEE Sys. Jour., Vol. 6, No. 2, pp. 242-253, Jun. 2012.

[160]G. Tsengenes and G. Adamidis, "A multi-function grid connected PV system with three level NPC inverter and voltage oriented control," Solar Energy, Vol. 85, No. 11, pp. 2595-2610, Nov. 2011.

[161]M. Abbes, J. Belhadj, and A. B. A. Bennani, "Design and control of a direct drive wind turbine equipped with 
multilevel converters," Ren. Energy, Vol. 35, No. 5, pp. 936-945, May 2010.

[162]J. A. Martı'nez, J. E. Garc1'a, and S. Arnaltes, "Direct power control of grid connected PV systems with three level NPC inverter," Solar Energy, Vol. 84, No. 7, pp. 1175-1186, Jul. 2010.

[163]I. Hamzaoui, F. Bouchafaa, and A. Hadjammar, "Investigation of the behavior of a three phase grid connected photovoltaic system to control active and reactive power with DPC," Energy Proc., Vol. 6, pp.493-502, 2011.

[164]M. Abbes and J. Belhadj, "New control method of a robust NPC converter for renewable energy sources grid connection," Electric Power Systems Res., Vol. 88, pp. 52-63, Jul. 2012.

[165]S. M. Muyeen, R. Takahashi, T. Murata, and J. Tamura, "A variable speed wind turbine control strategy to meet wind farm grid code requirements," IEEE Trans. Power Syst., Vol. 25, No. 1, pp. 331-340, Feb. 2010.

[166]S. Arezki and M. Boudour, "Linear enslavement of DC bus voltage of hybrid system wind-photovoltaic," Int. Symp. Envi. Frien. Ener. Appl., pp. 664-669, 2012.

[167]G. Karmiris, G. Tsengenes, and G. Adamidis, "A multifunction control scheme for current harmonic elimination and voltage sag mitigation using a three phase three level flying capacitor inverter," Simu. Mode. Prac. Theory, Vol. 24, pp. 15-34, May 2012.

[168]K. M. Tsang and W. L. Chan, "27-level DC-AC inverter with single energy source," Energy Convers. Manag., Vol. 53, No. 1, pp. 99-107, Jan. 2012.

[169]K. Mahendran, “Advanced cascaded multilevel inverter for PV cell renewable energy system employing incremental conductance MPPT algorithm," Int, Conf. Recent Adv.Elec., Electr. Cont. Eng., pp. 367-370, 2011.

[170]P. Sotoodeh, C. P. Tareila, and R. D. Miller, "A single-phase D-STATCOM inverter for distributed energy sources," North Ame. Power Symp., Cham., pp. 1-6, 2012

[171]T. Wanjekeche, D. V. Nicolae, and A. A. Jimoh, "Modeling and control of a cascaded NPC/H-bridge inverter with LCL filter in PV- Grid application," Conf, Proc., pp. 334-339, 2010.

[172]R. Bojoi, L. R. Limongi, D. Roiu, and A. Tenconi, "Enhanced power quality control strategy for single-phase inverters in distributed generation systems," IEEE Trans. Power Electron., Vol. 26, No. 3, pp. 798-806, Mar. 2011.

[173]M. Aguirre, H. Couto, and M. I.Valla, "Analysis and simulation of a hydrogen based electric system to improve power quality in distributed grids," Int. Jour. Hyd. Energy, Vol. 37, No. 19, pp. 14959-14965, Oct. 2012.

[174]J. M. Pacas, M. G. Molina, and E. C. dos Santos Jr., "Design of a robust and efficient power electronic interface for the grid integration of solar photovoltaic generation systems," Int. Jour. Hyd. Energy, Vol. 37, No. 13, pp. 10076-10082, Jul. 2012.

[175]H. Akagi, Y. Kanazawad, and A. Nabae, "Instantaneous reactive power compensators comprising switching devices without energy storage components," IEEE Trans. Ind. Appl., Vol. 20, No. 3, pp. 625-630, May/Jun. 1984.

[176]S. Bhattacharya and D. Divan, "Synchronous frame based controller implementation for a hybrid series active filter system," in Proc. $30^{\text {th }}$ Ind. Appl. Soc. Annu. Meet. Ind. Appl. Conf., pp. 2531-2540, Oct. 8-12, 1995.

[177]M. Castilla, J. Miret, J. L. Sosa, J.Matas, and L. G.Vicũna, "Grid-fault control scheme for three-phase photovoltaic inverters with adjustable power quality characteristics,"
IEEE Trans. Power Electron., Vol. 25, No. 12, pp. 2930-2940, Dec. 2010

[178]P. Rodr'1guez, A. Timbus, R. Teodorescu, M. Liserre, and F. Blaabjerg, "Reactive power control for improving wind turbine system behavior under grid faults," IEEE Trans..Power Electron., Vol. 24, No. 7, pp. 1798-1801, Jul. 2009.

[179]T. I. Lee and P. T. Cheng, "Design of a new cooperative harmonic filtering strategy for distributed generation interface converters in an islanding network," IEEE Trans. Power Electron., Vol. 22, No. 5, pp. 1919-1927, Sep. 2007.

[180]S. D. G. Jayasinghe, D. M. Vilathgamuwa, and U. K. Madawala, "Diode-clamped three-level inverter-based battery/supercapacitor direct integration scheme for renewable energy systems," IEEE Trans Power Electron., Vol. 26, No. 12, pp. 3720-3729, Dec. 2011.

[181]M. B. Delghavi and A. Yazdani, "An adaptive feedforward compensation for stability enhancement in droop-controlled inverter-based microgrids," IEEE Trans. Power Del., Vol. 26, No. 3, pp. 1764-1773, Jul. 2011.

[182]H. Karimi, A. Yazdani, and R. Iravani, "Robust control of an autonomous four-wire electronically-coupled distributed generation unit," IEEE Trans. Power Del., Vol. 26, No. 1, pp. 455-466, Jan. 2011.

[183]N. Altin and I. Sefa, "dSPACE based adaptive neuro-fuzzy controller of grid interactive inverter," Energy Convers. Manag., Vol. 56, pp. 130-139, Apr. 2012.

[184]V. Ilavarasi and C. C. A. Rajan, "Power quality improvement in grid connected system using four leg VSI," IEEE Int. Conf. Adv. Eng., Sci. Man., pp. 540-546, 2012.

[185]B. Shyam, B. R. Aswathy, and P. C. Thomas, "A novel wind energy conversion system with power quality improvement features," Conf. Innov. Smart Grid Tech., pp. 84-88, 2011.

[186]H. Yamauchi, K. Uchida, A. Yona, and T. Senjyu, "Intelligent operations of distribution system with distributed generators," Int. Conf. Rene. Energy Res. Appl., pp. 1-6, 2012.

[187]G. Weiss, Q. C. Zhong, T. C. Green, and J. Liang, " $\mathrm{H}^{\infty}$ repetitive control of DC-AC converters in microgrids,"IEEE Trans. Power Electr., Vol. 19, No. 1, pp. 219-230, Jan. 2004.

[188]S. Luo, An. Luo, Zhipeng. Lv, Y. Shen, Lu. Guo, and Wenqian. Jiang, "Power quality active control research of building integrated photovoltaic," IEEE $2^{\text {th }}$ Int. Symp. Power Electr. Distri.Gener. Syst., pp. 796-801, 2010.

[189]F.Wang, J. L. Duarte, and M. A. M. Hendrix, "Grid-interfacing converter systems with enhanced voltage quality for microgrid application concept and implementation," IEEE Trans. Power Electr., Vol. 26, No. 12, pp. 3501-3513, Dec. 2011

[190]T. I. Maris, S. Kourtesi, L. Ekonomou, and G. P. Fotis, "Modeling of a single-phase photovoltaic inverter," Solar Energy Mater. Solar Cells, Vol. 91, No. 18, pp. 1713-1725, Nov. 2007.

[191]Z. Zeng, H. Yang, R. Zhao, and C. Cheng, "Topologies and control strategies of multi-functional grid-connected inverters for power quality enhancement: A comprehensive review," Renewable and Sustainable Energy Reviews, Vol. 24, pp. 223-270, Aug. 2013.

[192]M.M.N. Amin and O.A. Mohammed, "Power quality improvement of grid-connected wind energy conversion system for optimum utilization of variable speed wind turbines," $36^{\text {th }}$ IEEE Conf. Ind. Electr. Soc., pp. 3287-3292, 2010 . 
[193]Z. Lv, A. Luo, C.Wu, Z. Shuai, and Z. Kang, "A research of microgrid energy supply and filtering system based on inverter multiplexing," IEEE Int. Conf. on Sust. Power Gen. Supply, pp.1-7, 2009.

[194]B. Han, B. Bae, H. Kim, and S. Baek, "Combined operation of unified power-quality conditioner with distributed generation," IEEE Trans. Power Del., Vol. 21, No. 1, pp. 330-338, Jan. 2006.

[195]A. B. R. Boué, R. G. Valverde, F. A. R. Vila, and J. M. T. Ponce, "An integrative approach to the design methodology for 3-phase power conditioners in photovoltaic grid-connected systems," Energy Convers. and Manag., Vol. 56, pp. 80-95, Apr. 2012.

[196]Y. S. Lim and J. H. Tang, "Experimental study on flicker emissions by photovoltaic systems on highly cloudy region: A case study in malaysia," Renewable Energy, Vol. 64, pp. 61-70, Apr. 2014.

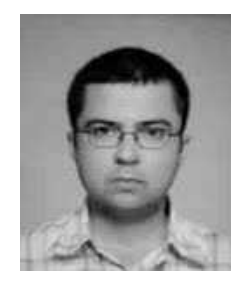

Ahmet Teke received his B.S., M.Sc., and $\mathrm{Ph} . \mathrm{D}$. degrees in electrical and electronics engineering from Cukurova University, Adana, Turkey in 2002, 2005, and 2011, respectively. He is currently an assistant professor at the Department of EEE, Cukurova University. His current research interests include custom power devices, renewable energy sources, control of power electronic converters, PWM modulation techniques, multifunctional inverters, and power system harmonics.

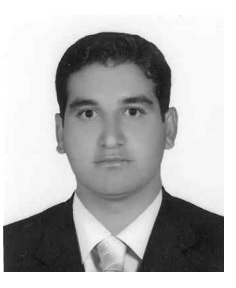

Mohammad Barghi Latran received his B.S. and M.Sc. degrees in electrical and electronics engineering from Islamic Azad University Ardebil Branch, Ardebil, Iran, in 2007 and from Hacettepe University, Ankara, Turkey, in 2012, respectively. He is currently pursuing his Ph.D. degree at the Department of EEE, Cukurova University, Adana, Turkey. His current research interests include applications of power electronics in distribution systems, power quality enhancement, active power filters, static VAR compensators, applications of power electronics in renewable energy resources, and grid interconnection issues. 